\title{
Hydrogeological evolution of the Luni river basin, Rajasthan, western India: A review
}

\author{
V N BAJPAI \\ Department of Geology, University of Delhi, Delhi 110 007, India. \\ e-mail:vnbajpai@yahoo.com
}

The Luni river basin has been evolved as a result of typical hydrogeomorphic processes of arid zone, operating under the influence of active tectonic lineaments. A detailed analysis of stream morphology in relation to geology and lineaments carried out on selected windows indicated the morphological control of the streams while flowing over the lineaments from the eastern to the western part of the basin. Typical valley fills indicated by dark green tone on digitally processed images and the pediments showing greenish white tone appear in sharp contrast and indicate respectively the graben and horst structures. A detailed identification of lineaments for the georesources and geological evaluation has been carried out. Earlier analysis carried out on Bouguer anomalies correlate with graben and horst structures in the subsurface. Quaternary sequences have been dated from $80 \mathrm{ka}$ to $3 \mathrm{ka}$ indicating a range of fluvial to aeolian deposits reflecting prevailing climatic conditions. However, the changes in sediment type from coarse and mixed of all size grades to fine in a vertical litho-column warrant further studies on fine resolution stratigraphy and high resolution stratigraphy for understanding climatic variations in the region.

\section{Introduction}

Luni basin being the major fluvial basin of the Thar desert in western India is an active tectonic basin where more than $300 \mathrm{~m}$ sediment accumulation has been reported (Bajpai et al 2001a). This is possibly due to subsidence in response to E-W faulting along the Sukri river (Henry et al 1983). Deposition has taken place over an uneven basement as indicated by negative gravity anomalies across the basin (Bajpai et al 2001a). The basin is traversed by major lineaments: JaisalmerBarwani lineament trending NW-SE, Luni-Sukri lineament trending NE-SW (Ramasamy et al 1991; Dhir et al 1992), which intersect in the southwestern part of the basin at Jhab (Pal 1991) and partly Tonk-Raisinghnagar lineament NW-SE (Roy and Jakhar 2001) and also by several parallel major and minor lineaments. Lineaments have controlled the channel processes and the spatial distribution of flood damages (Kar 1994). Delineation of lineaments is significant in terms of locating groundwa- ter resources, and oil reserves particularly in the Barmer region.

Climate in the basin is semi-arid. Torrential and episodic rainfall (Bell 1979; Sharma and Chatterji 1982; Sharma et al 1984; Wheater 2002), intense physical weathering (Goudie and Wilkinson 1977), sparse vegetation cover (Pilgrim et al 1988) and aeolian surface deposits (Jones 1981) give rise to an overall abundance of transportable material of all size grades (Reid and Frostick 1987). Flash flood regime further favours the availability of a higher volume of sediments and consequent influx and accumulation gives rise to thick sediment deposits (Abdullatif 1989). Besides nearly 400 times of the bedload sediment transport is possible by the ephemeral rivers in contrast to its perennial counterpart in the humid zones (Laronne and Reid 1993).

Inspite of the work carried out on the different aspects of the Luni basin, work is still required on the following:

Keywords. Lineament; graben; Bouguer anomaly; FCC image; valley fill, pediment. 
- A detailed classification of major and minor lineaments and their influence on hydrogeomorphic processes.

- A co-relative evaluation of the lineaments for georesources.

- Type of geological material filled in the basin at least to a shallow depth of about $50 \mathrm{~m}$.

- Relation of aquifer geometry with major and minor lineaments.

In view of the above, a detailed map showing major and minor lineaments has been prepared and the relation of lineaments with geological and geomorphic situation has been worked out. Field survey of hydrogeological sections along E-W reported in the earlier work (Bajpai et al 2001a) based on tube well lithologs have been utilized to find out the relation of aquifer geometry with lineaments. A co-relative evaluation of lineaments has also been provided in terms of georesources.

\section{Geology}

Geological mapping of the area in the basin has been attempted by several workers (Heron 1917; Roy 1959; G.S.I. 1976; Gupta et al 1980; Pareek 1981, 1984; G.S.I. 1982; Wadhawan et al (1999) and Sareen 2002). A map has been prepared following the relevant authors (figure 1). The formations in the basin range from Banded Gneissic Complex (Archaean) to alluvium and aeolian sand (Quaternary-Recent). While the eastern margin of the basin consists of formations of Aravalli and Delhi Supergroups, the western part shows the exposures of Malani Volcanics and Cretaceous-Carboniferous formations in Barmer region. Cretaceous-Carboniferous sequences occur with faulted contact with Malani rhyolites and granites (G.S.I. 1982). The central and southern parts of the basin are occupied by Malani granite (Jalor and Erinpura granites) with few patches of rocks of the Delhi Supergroup. The rocks of Marwar Supergroup are distributed in the northern and northeastern parts. The western and central parts are occupied by Quaternary alluvium, blanketed by aeolian sand sheet and sand dunes.

A detailed account of stratigraphy together with facies analysis of the exposed bank sections along the Luni river in Barmer region from Karna to Khudala has been provided by Jain et al (1999). Three types of lithological sequences termed as type I, type II and type III were identified. Type I (Sindari/Bhukan) sequence represented semi-arid gravel-sand bedload and slackwater deposits, type II represented significantly aeolian with implementiferous pebbly sandstones and type III sequence represents pottery bearing pebbly coarse sands and silts. Artifacts have been reported from the gravel of type II sequence which gave the age around $80 \mathrm{ka}$ (Mishra et al 1999) dated by IRSL (infrared simulated luminescence method) technique. The age of type I, type II and type III sequences are tentatively assigned to early to middle Pleistocene, late Pleistocene and Holocene respectively, on the basis of luminescence measurements and archaeological data.

Tectonically the basin lies within the west Rajasthan Shelf (Bakliwal and Wadhawan 2003). The eastern part has the Aravalli mountains and the northwestern part has Jaisalmer basin and partly the Indian shield. On the basis of gravity and magnetic surveys, Oil and Natural Gas Commission has given the major divisions as Nagaur basin, Pokran - Nachna high, Barmer graben, Sarnu high, Sanchore basin and Tharad high. Sarnu high separates the Barmer basin from the Sanchore basin situated in the south. The Tharad high situated to the south of the Sanchore basin appears to be the projection of main Aravalli orogenic trend (Das Gupta and Chandra 1978).

The Bouguer anomaly cross-sections (Bajpai et al 2001a) demarcated as 1-1, 2-2, 3-3 and 4-4 (figure 2) in the geological map (figure 1) indicate the buried basement irregularities across the Luni river basin (figure 2). In section 1-1, there is a high on the east of Lik river which shows fault towards the west near Bhiyar. In the eastern part, the major graben structure is in vertical alignment of many rivers of Luni system. In section 2-2, the Luni river on either side of Sindari shows fault corresponding to high difference of gravity, about $30 \mathrm{mgal}$ with respect to the lowest value of -20 mgal. In the eastern part also, a regional depression is indicated in the basement, which is coincident with the tributary streams of Luni system. In section 3-3, similarly the faults are indicated on either side of the Luni river. Towards east in this section a graben structure is indicated along the Bandi - Sukri river. In section 4-4, the faults are indicated along Luni, Bandi and Jawai rivers. Rivers of the Luni system here also occupy the lines (vertically upwards) above the depressions indicated in the gravity profiles.

\section{Distribution of Quaternary sediments and the depth to the basement}

Field survey and investigations were carried out of geological material excavated out of various dug wells and tube wells, right from east to west. Mostly mixed material of all size grades, rounded to angular, and alternating with fluvial clay, kankar and sand and aeolian fine sand dominate. A generalized description of geological material varying with depth is given in figure 3 , and depth variations 
Figure 1. Geological map of the Luni river basin (after Roy 1959; G.S.I. 1976; Gupta et al 1980; G.S.I. 1982; Pareek 1981, 1984). 

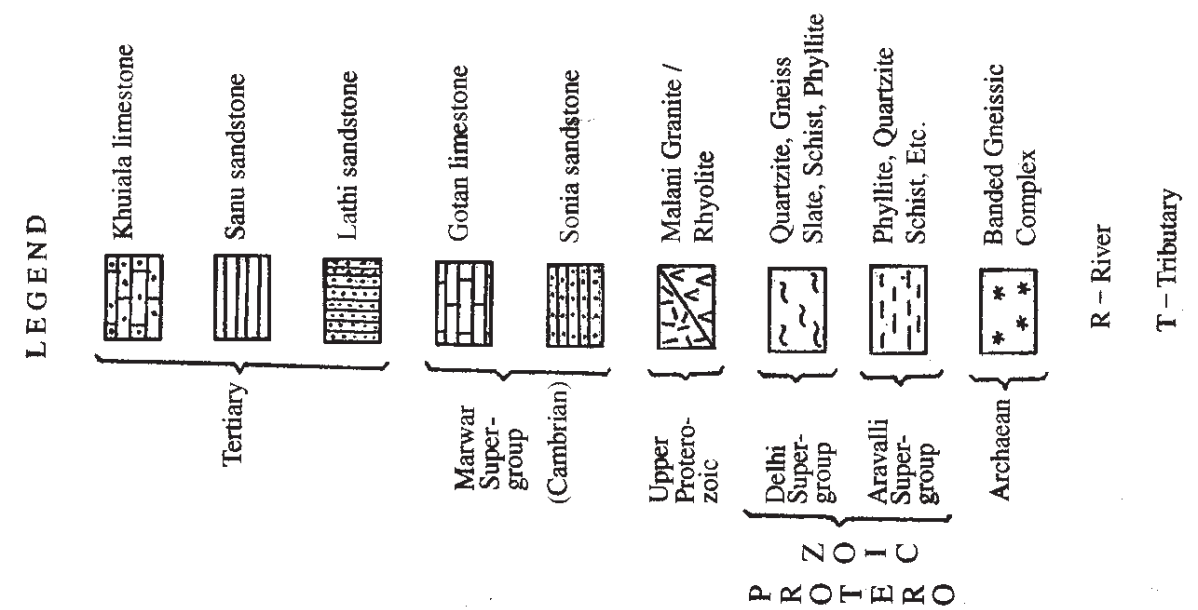

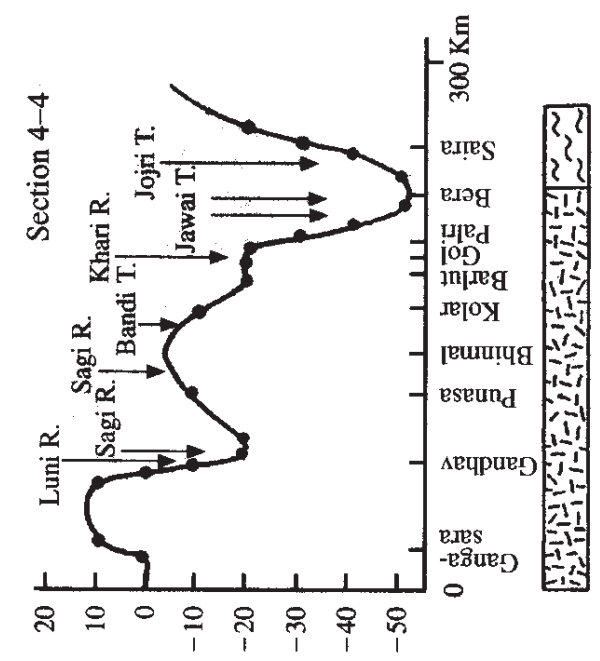

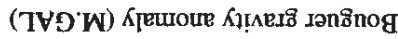

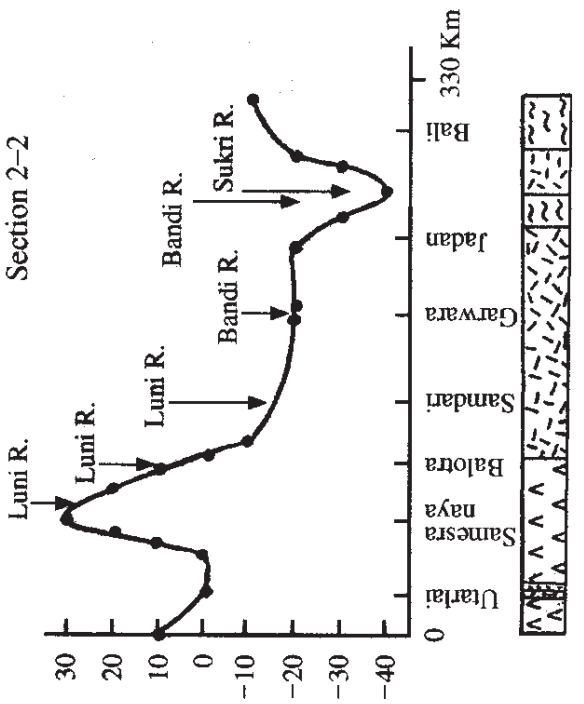

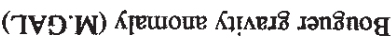




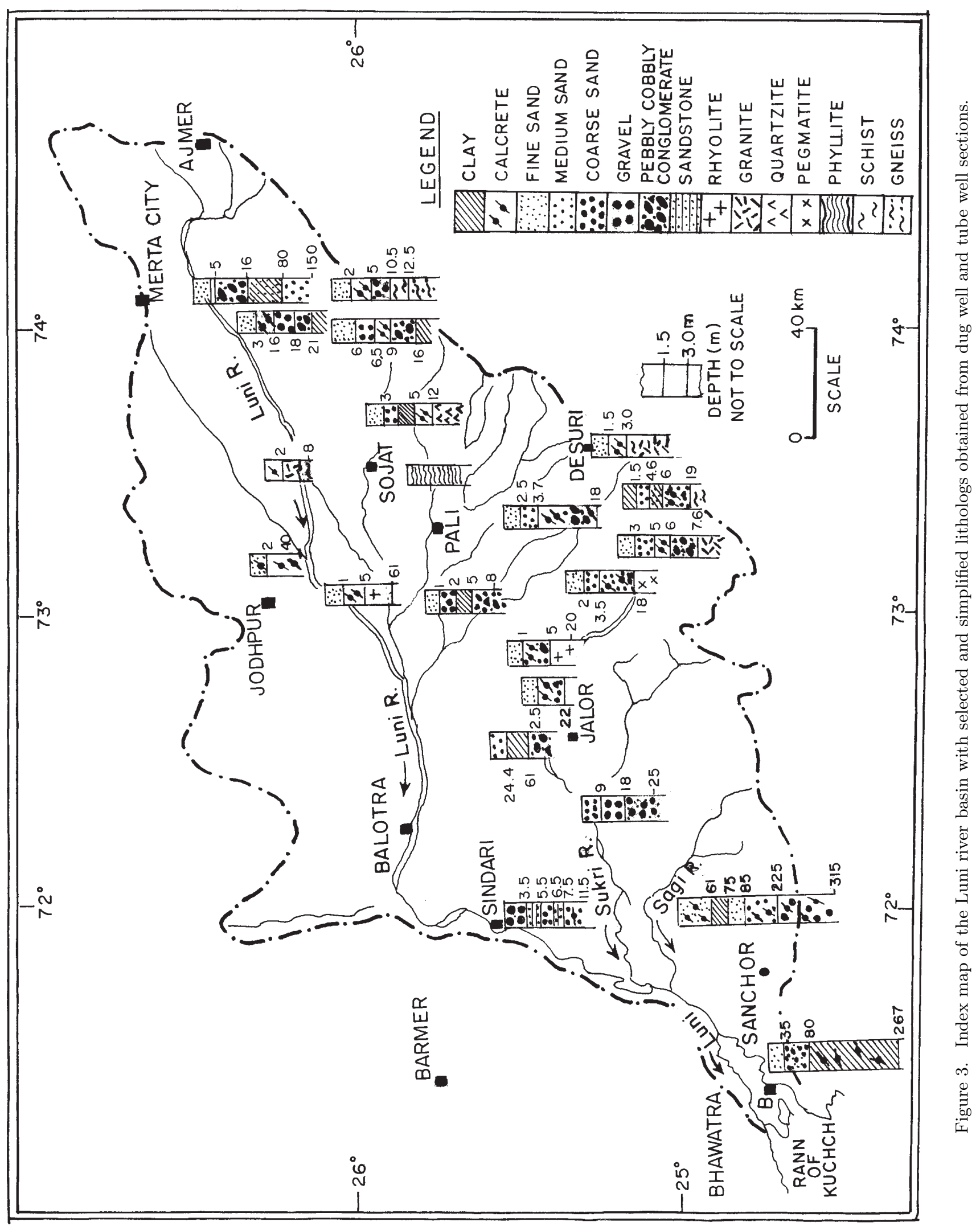


of alluvium over the basement (at places depth to basement not known) is given in the figure 4 .

The geological material in the wells from east to west and above the basement consists of pebblycobbly conglomerate, gravel, coarse sand, fine sand, calcrete and clay. Calcrete and fine sand increase towards Jodhpur.

To the south and southwest of Merta city (figure 4) there is a depression filled with alluvium. Towards the west and central part of the basin, depth to basement is limited to the order of 18 to $20 \mathrm{~m}$. Further west towards Jalor and Sindari, the thickness of alluvium increases. At Sindari, the rhyolite basement occurs at a depth of $42 \mathrm{~m}$. To the SW of Jalor the thickness increases towards Sanchor to an extent of about $300 \mathrm{~m}$ along the LuniSukri lineament extending in NE-SW direction. The thickness of Quaternary sediments reduces considerably to the NE of Jalor to the west of Pali following the Luni-Sukri lineament zone. It is possible that the Luni-Sukri lineament in this region behaves like a hinge fault with increased throw towards SW, thus accommodating greater thickness of alluvium towards SW. Besides, the block developed in this region (around Sanchor) by intersection of Jaisalmer-Barwani and LuniSukri lineament at Jhab, must have subsided more as compared to other blocks, thus giving rise to increased thickness of sediments. Luni-Sukri lineament appears to recharge groundwater from NE, as the artesian conditions have been found at Bijrol Ka Golia (N of Sanchor) situated towards SW of the basin, where the thickness of sediments is more than $300 \mathrm{~m}$.

On the basis of the availability of the geological material in the basin, general comments on the hydrogeological evolution can be made:

The basin had uneven basement topography with the occupation mostly of Erinpura granite and Malani granite and rhyolite, followed by Bilara limestone, Girbhakar and Sonia sandstones of Marwar Supergroup towards NE. In the west, to the outside of the basin the Malani rhyolites and granites occur in faulted contact with CretaceousCarboniferous sequences. On such a basement, the Quaternary deposits have evolved though the deposition of material of all size grades and changing roundness. However, the presence of Tertiary formations, below the Quaternary sediments cannot be ruled out, particularly in the southwestern part of the basin.

In the lower part of the Luni basin which receives a precipitation between $200 \mathrm{~mm}$ and $300 \mathrm{~mm}, 6$ distinct depositional environments have been identified (Jain and Tandon 2003) in the late Quaternary type II successions. These depositional environments are (a) Gravel bedload braided streams, (b) ephemeral sand bed streams, (c) sediment gravity flows (sheet flows), (d) sheet flows, (e) mixed load meandering streams and (f) aeolian dunes. Out of the sections described by Jain et al (2003), gravel-sand bedload braided streams during Oxygen Isotope Stage (OIS) 5, generally occurs at the base of these sections. The relatively older deposits near Khudala (>90 ka) perhaps deposited at the beginning of late Pleistocene succession (OIS 5e) are without flood plain development. Lesser wet phases such as OIS 3 are represented by sediment gravity flows and ephemeral sand bed streams (cf. Mishra and Rajaguru 2001).

The aeolian phase was followed with a gap by fluvial activity around $14 \mathrm{ka}$ with incision and later deposition by gravel bedload braided streams (OIS 1). OIS 1 (11-14 ka) was a period characterized by high frequency climatic fluctuations and shows a spectrum of gravel-sand braided, meandering, sand bed ephemeral streams and aeolian. A second phase of incision occurred during the early Holocene, this was followed by sheet flow aggradation between 5 and 9 ka corresponding to rapidly fluctuating lake levels during the early and middle Holocene (Enzel et al 1999). During the arid phase around $3 \mathrm{ka}$ the streams became defunct as evident by the presence of aeolian dunes in the stratigraphic records. The subsequent wet phase after 3 ka caused the third incision that resulted in the present day sand bed Luni river channel.

\section{Hydrogeomorphology}

Hydrogeomorphic map of the basin, prepared in detail by using Landsat 1 and 2 images and IRS1B LISS-I images (Bajpai et al 2001b), has been presented in figure 5 . The major morphologic units classified are rocky tracts, buried pediments, valley fills, flood plains, palaeochannels and dune fields. The hydrogeomorphic variations are influenced by major and minor lineaments (Kar 1992, 1994; Bajpai et al 2001a). The palaeodrainage system analysis of the Luni river system observed on the radar images indicated that former Luni system joined directly the Sukri (Kar 1999) and the same is also indicated in the subsurface by continuous sand bodies between upper Luni and present NE-SW trending Sukri (Mandawla-Surana region, following the Luni-Sukri lineament (Bajpai et al 2001b).

The aquifers formed in coarse sand and gravel of laterally pinching type formed in interridge areas or grabens are indicated in Jodhpur region in the vicinity of Golasani river, Digrana-Bhawal graben, Bhadrajan-Dewan region, Bhimgoda-Juna Motisara graben, Sindari-Khudala depression and in Ratanpura-Khanpur graben (Bajpai et al 2001a). Aquifers and their geometry reflect control by paleo-fluvial geomorphic processes over the entire basin. A general pinch and swell character is common with the aquifers in alluvium. 


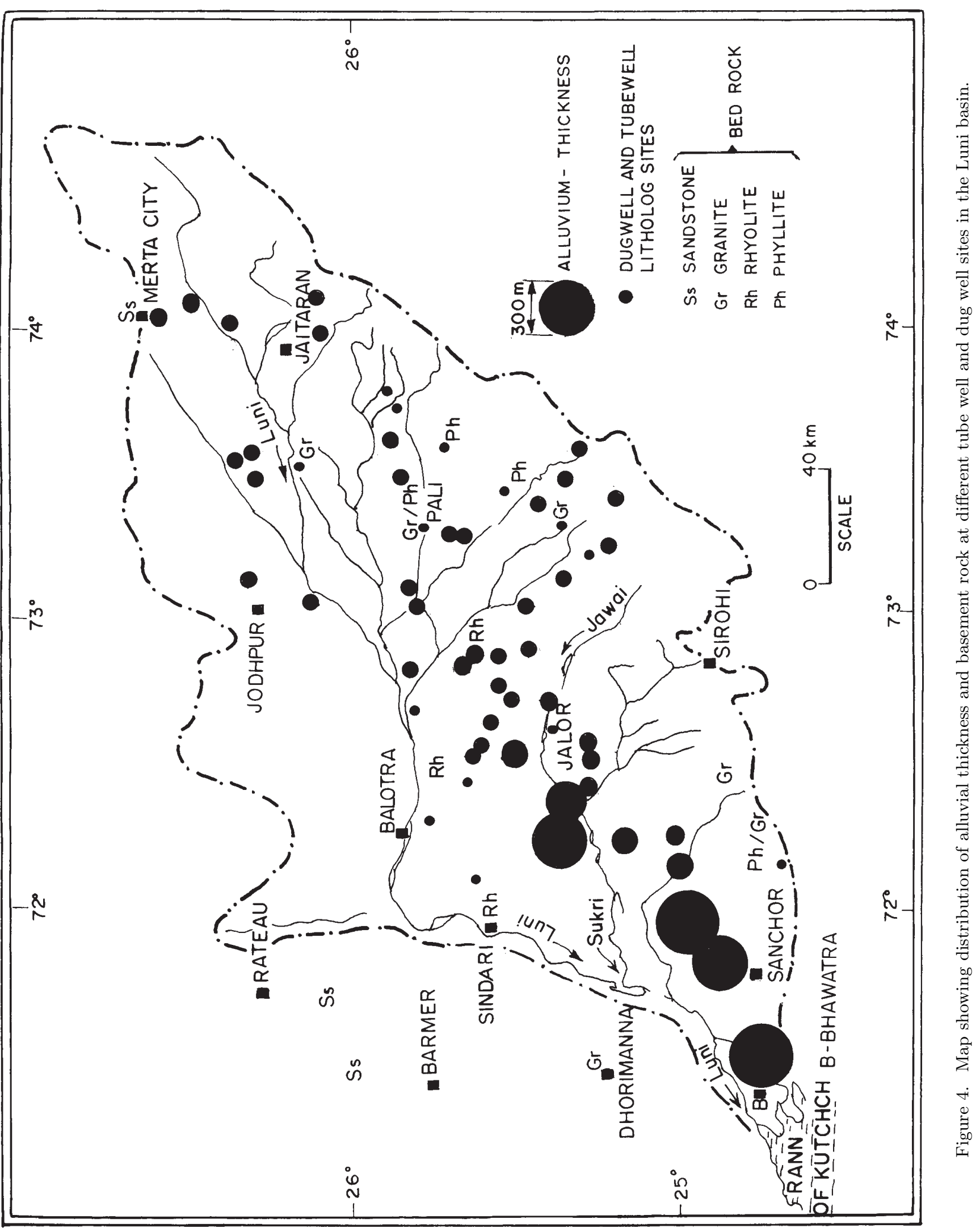


In order to understand the hydrogeomorphic processes in relation to lineaments and subsurface geologic structure an analysis of lineaments together with drainage network flowing across the lineaments has been carried out. A detailed map of major and minor lineaments of the Luni river basin has been prepared in the present work (figure 6). The numbers e.g., 1-1 refer to the particular number of lineament indicated in figure 6 .

\section{Lineament classification in relation to geomorphic features and georesource evaluation}

Lineaments identified and mapped on multidate Landsat (1, 2 and TM) and IRS-1C, LISS III images are presented in figure 6 . The present lineament map has an addition of several lineaments identified earlier by Bajpai et al (2001a). Lineaments have been classified into various categories. Out of 91 main lineaments selected for classification in the present work, 5 belong to straight to curvilinear structural ridges, 17 to buried pediment-valley fill contacts, 1 to straight interdunal depression, 32 to straight river segments (active channels), 13 to straight dry channels (active only during the monsoon period), 1 to a regional fault (deep dislocation), 6 to straight moisture zones with water bodies and vegetation, 4 to straight topographic contrasts, 1 to straight natural vegetation border, 1 to straight fracture zone within rocky tract, 4 to escarpments and 6 to straight and sharp lithologic contacts. Lineaments, that are closely distributed and parallel have been numbered as a group of lineaments. As there is no minimum length of lineaments, in the present work, the lineaments more than $10 \mathrm{~km}$ in length are classified as major lineaments. Most of the lineaments do not belong to one category (simple lineaments), rather a combination of different categories: composite lineaments (Sabins 1987; Bajpai and Fallah Pour 1998). The categories of lineaments, their extension, their reflection behaviour on satellite images, and their geomorphic control together with georesource evaluation has been given in the following table 1.

For more detailed observations and understanding of hydrogeomorphic processes, the selected IRS-1C LISS III digital images (windows) have been produced in the central and western parts of the basin. These are as follows:

\subsection{Balwara - Birana - Sena window}

The image of this window belongs to IRS-1C (P92R54, 29 Dec 1996) and is FCC (BGR-234 : Linear Enhancement). The window encompasses the area around Siwana granites in the NW and further towards south the Sukri river and its tributaries (figure 7). Balwara lineament (N-S) intersects with Luni-Sukri lineament to the south of Balwara near the Sukri river. The Sukri river takes a southwesterly turn after this intersection. The dark tone to the NE of Balwara along Luni-Sukri lineament indicates moisture, while to the SW of Balwara along the Sukri river the pink tone indicates vegetation. The E-W trending parts of Sukri and Khari rivers indicate thick vegetation zones (figure 7) which are possibly the E-W trending deep fracture zones controlling these rivers. For detailed observations 3 windows of 1000 by 1000 pixels $(1$ pixel $=$ $23.5 \mathrm{~m}$ ) and 1 window of 681 by 681 pixels have been selected out of this sector. The first three windows are Root Enhancement Images, where the contrast is maximum. The fourth window shows contrast in Adaptive Equalization Enhancement. The windows are described as follows:-

\subsection{Balwara - Bharwani window}

This window encompasses Luni-Sukri lineament zone passing through Bharwani on one side and Bhavrani on the other and Sanwarla-Raithal lineament (north of Raithal with N-S trend). These lineaments have been described earlier by Kar (1994). On this window the geomorphic pattern in terms of buried pediment (appearing with rectangular blocks of light greenish white tone with NE-SW trend, location BP, figure 8) alternate with wide graben structures with dark greenish tone (valley fills, Location VF, figure 8). The river adjustment is by incising the pediments and getting braided within grabens. This is illustrated by Mithri river to the east of Bharwani. The rivers also get disorganized and disappear as it appears to the west of Bhavrani. The entrenched meanders indicate the response to the areas of uplift (Burnett and Schumm 1983; and Ouchi 1985), which are here buried pediments. The heavy bedload falling into areas of subsidence (grabens) indicate braiding as a river adjustment. Shallow groundwater exploitation together with agricultural practices is common along these braided and disorganized streams and on buried pediments, as the deep groundwater (beyond $40-50 \mathrm{~m}$ ) in grabens (deep valley fills) is saline. Sand dunes are mostly clustered on buried pediment regions (SW of Balwara and W of Raithal, figure 8) where they provide recharge of fresh quality of groundwater to buried pediment areas.

\subsection{Jalor - Mera window}

This window encompasses Jalor - Mera - Narnawa region to the south of Sukri river. Ridge-pediment- 
Figure 5. Hydrogeomorphic map of the Luni river basin prepared by using satellite images (after Bajpai et al 2001b). 


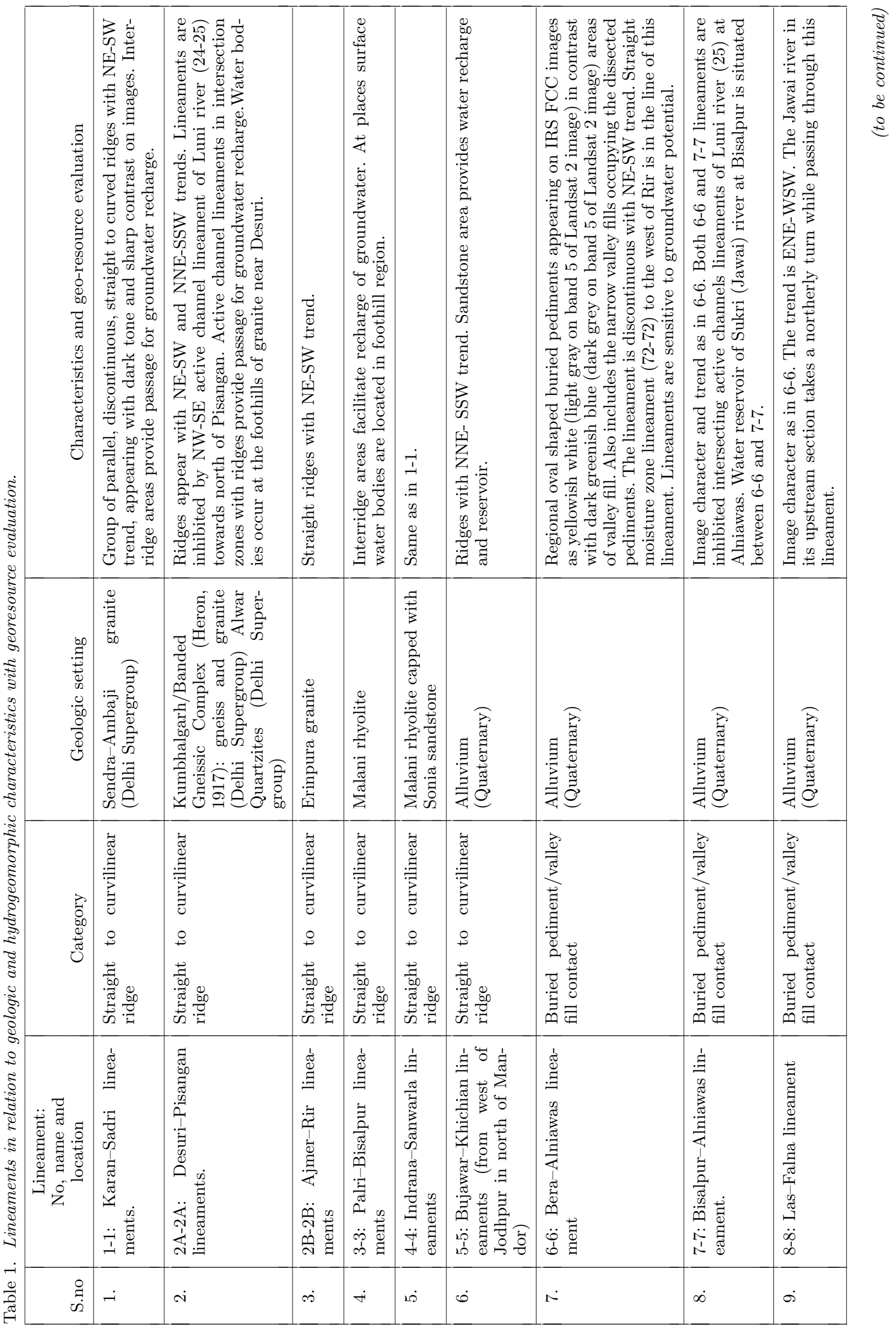


Figure 6. Lineament classification map of the Luni river basin prepared by using IRS and Landsat images (modified after Bajpai et al 2001a). 


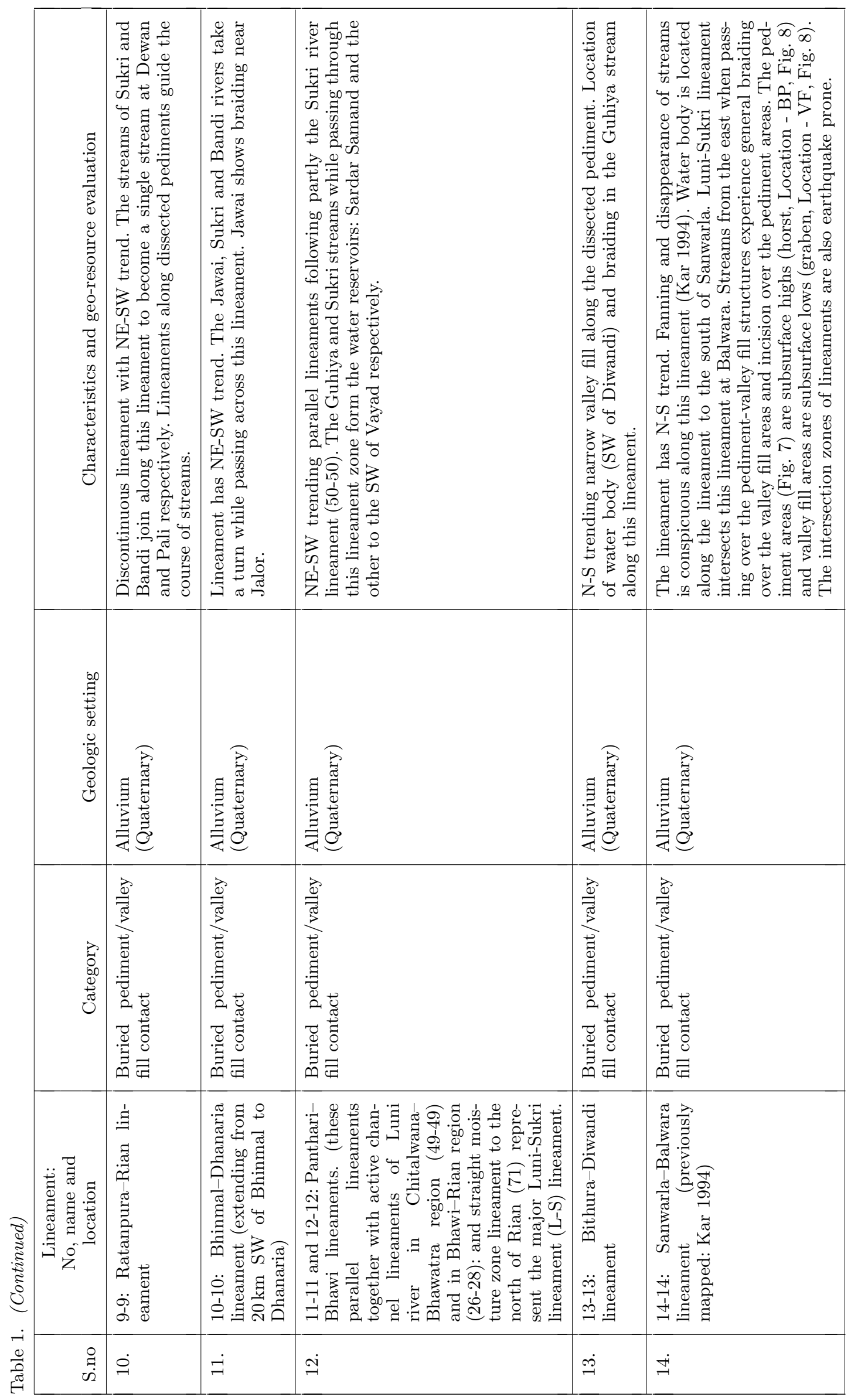




\begin{tabular}{|c|c|c|c|c|c|c|c|}
\hline 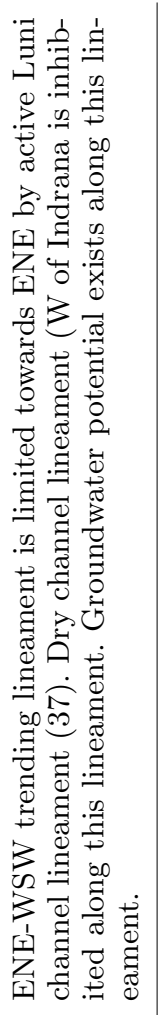 & 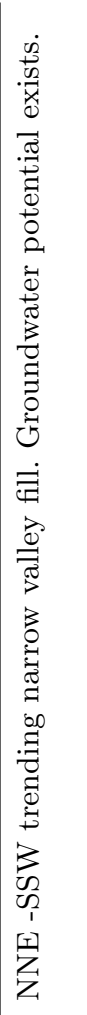 & 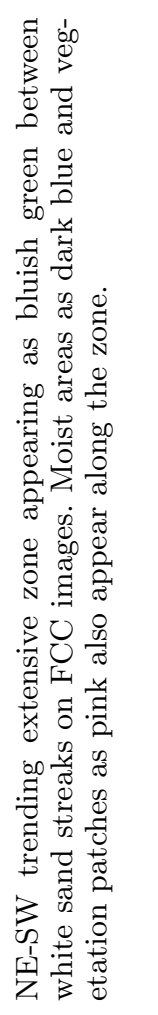 & 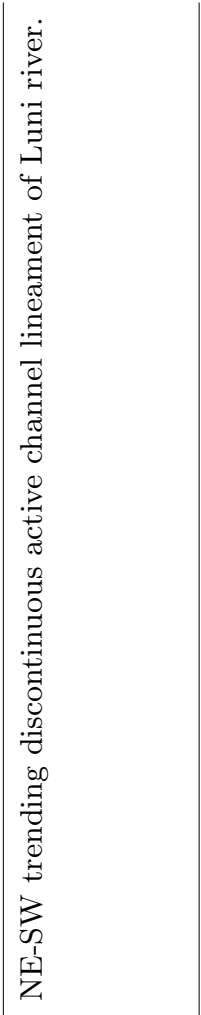 & 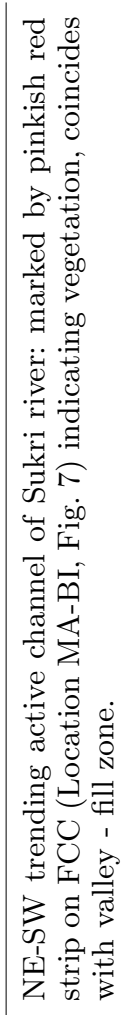 & 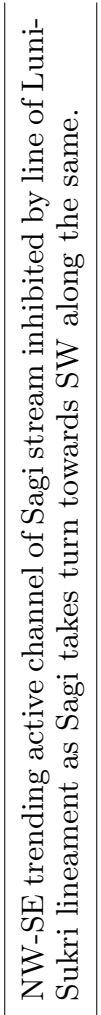 & 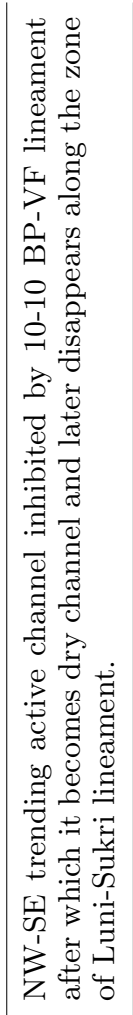 & 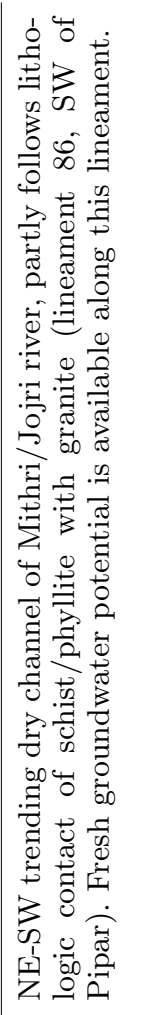 \\
\hline 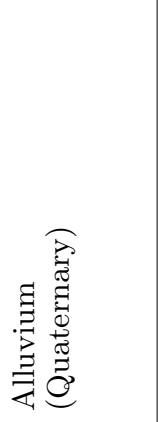 & 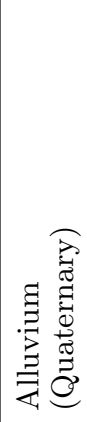 & 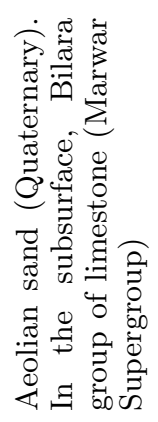 & 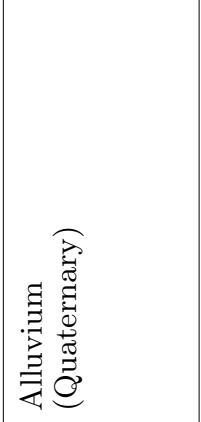 & 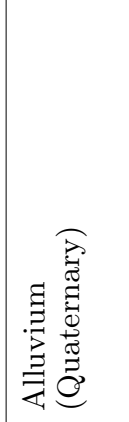 & 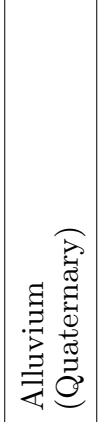 & 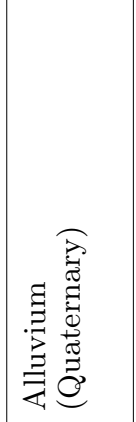 & 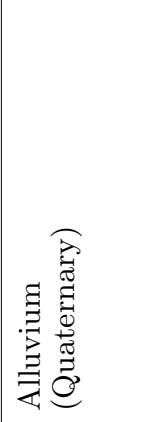 \\
\hline 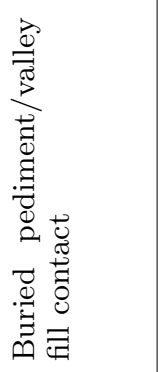 & 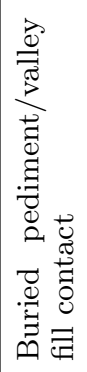 & 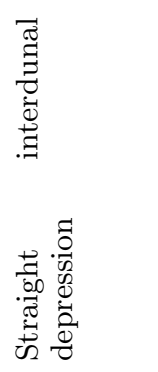 & 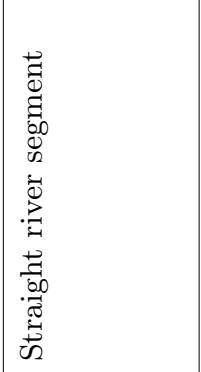 & 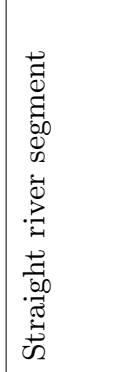 & 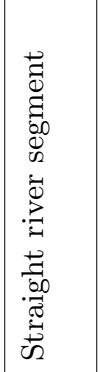 & 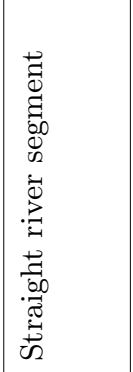 & 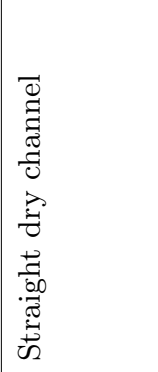 \\
\hline 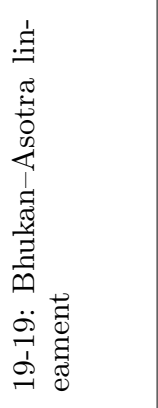 & 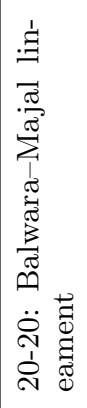 & 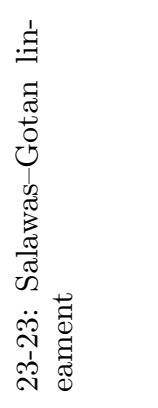 & 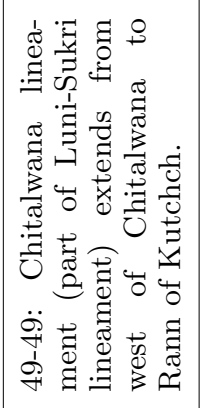 & 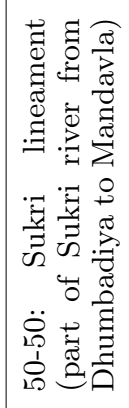 & 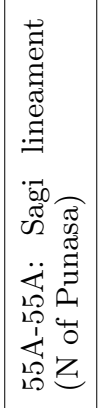 & 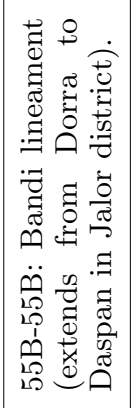 & 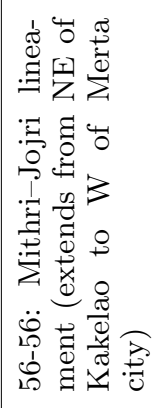 \\
\hline$\stackrel{\Delta \vec{g}}{\longrightarrow}$ & $\stackrel{\dot{\vartheta}}{ }$ & $\stackrel{\sim}{二}$ & $\stackrel{\dot{\infty}}{-}$ & $\underset{\infty}{\infty}$ & $\stackrel{\dot{\Omega}}{\rightarrow}$ & $\dot{\sim}$ & $\dot{\mathrm{N}}$ \\
\hline
\end{tabular}




\begin{tabular}{|c|c|c|c|}
\hline 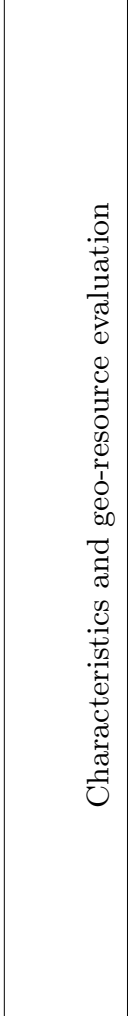 & 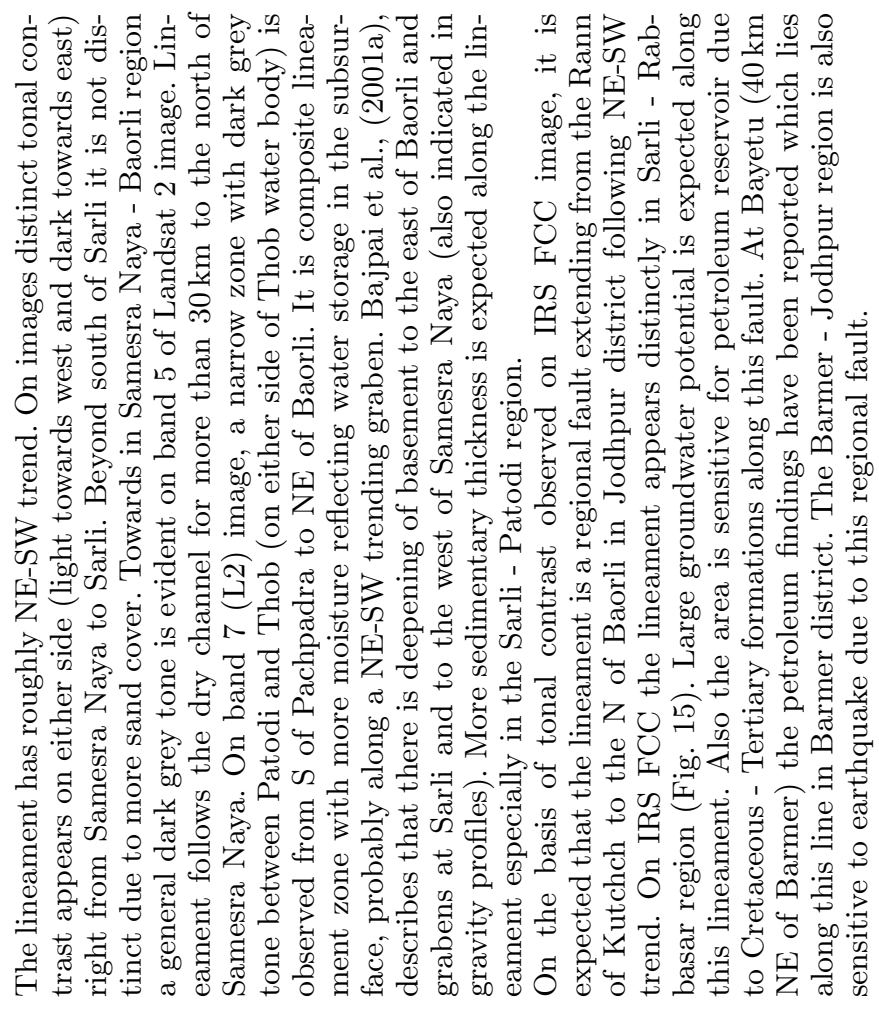 & 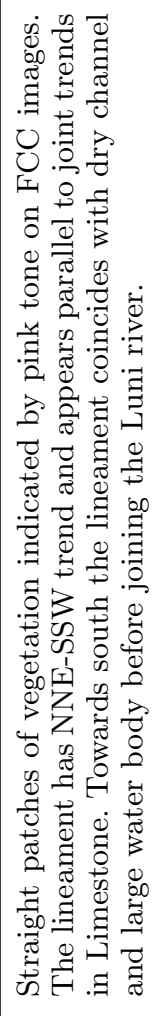 & 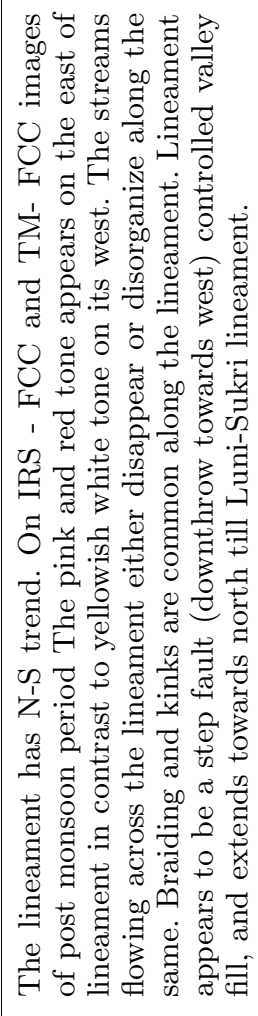 \\
\hline $\begin{array}{c}0 \\
\stackrel{0}{7} \\
\overrightarrow{0} \\
0 \\
0 \\
.0 \\
0 \\
0 \\
0 \\
0 \\
0 \\
0\end{array}$ & 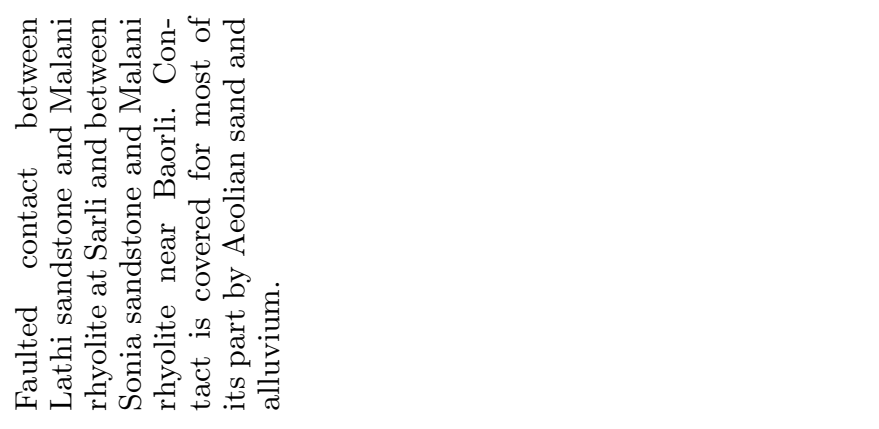 & 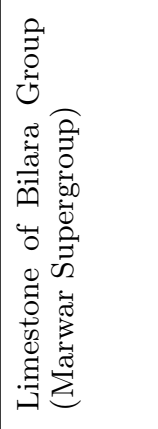 & 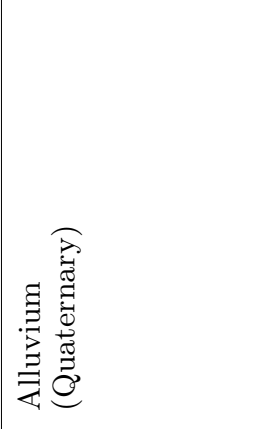 \\
\hline 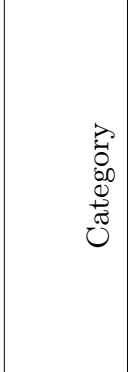 & 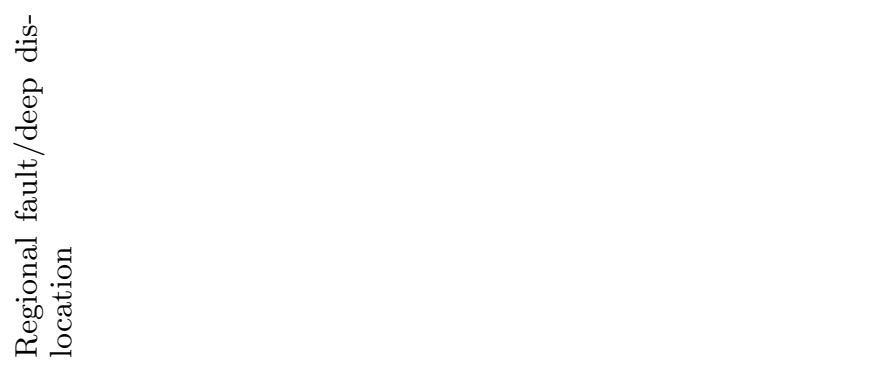 & 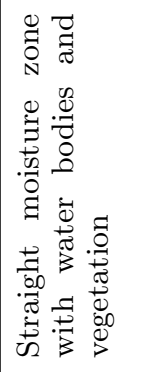 & 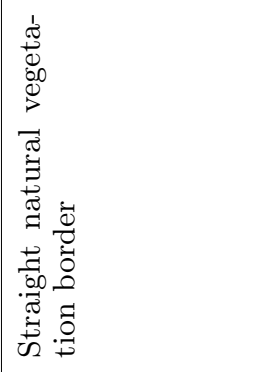 \\
\hline 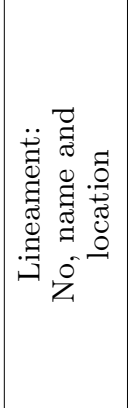 & 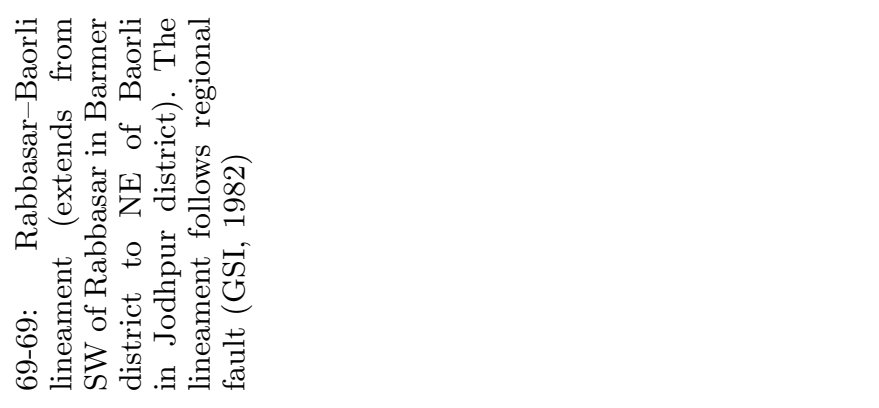 & 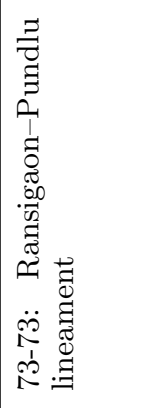 & 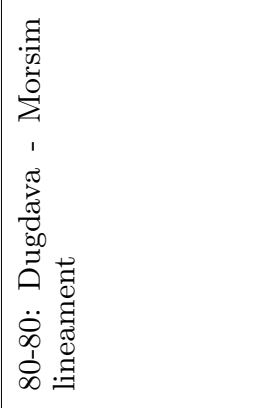 \\
\hline $\begin{array}{c}\stackrel{9}{\not} \\
\dot{R}\end{array}$ & ล่ & $\stackrel{\sim}{\sim}$ & $\stackrel{\leftrightarrow}{\sim}$ \\
\hline
\end{tabular}




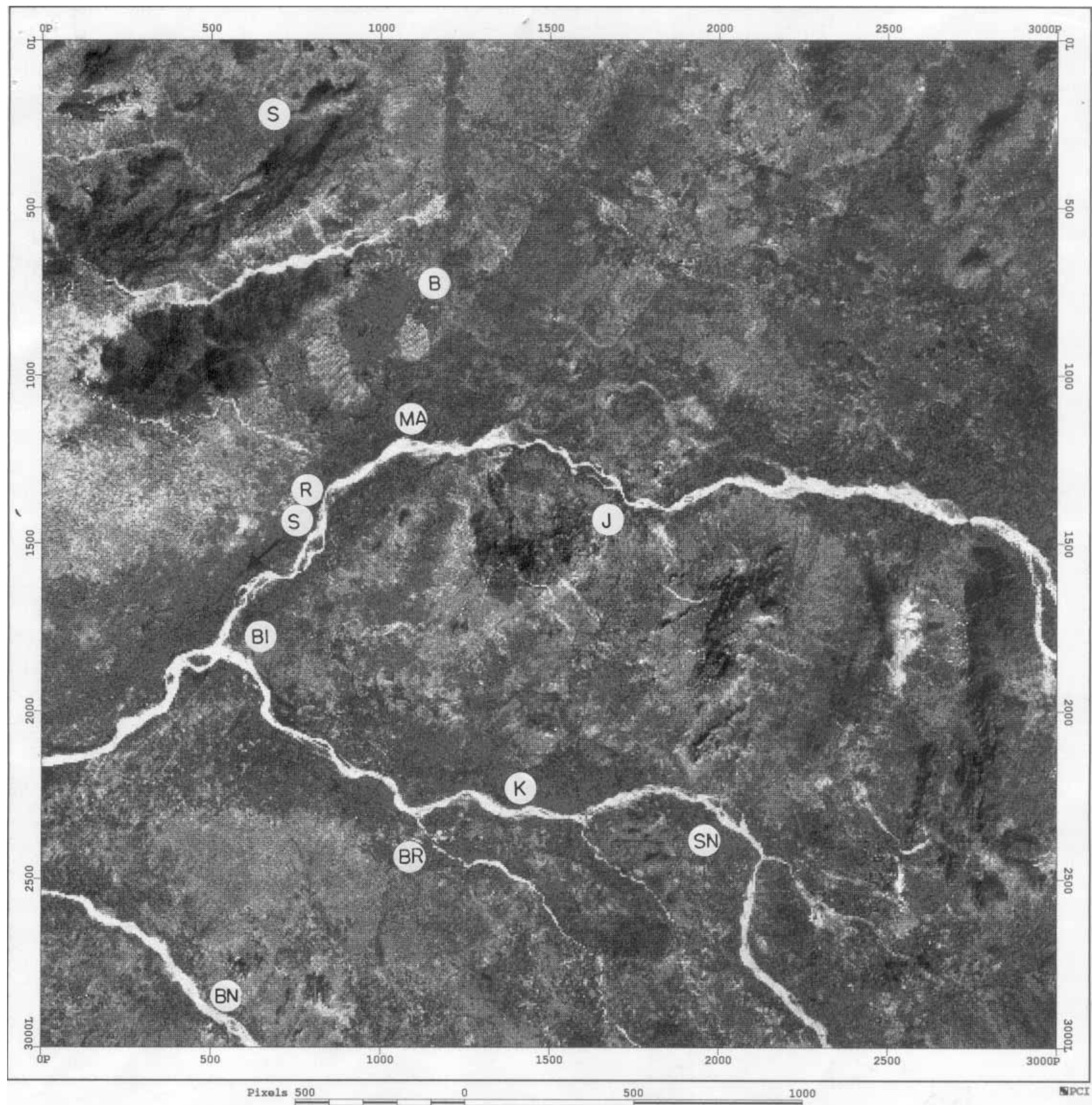

Figure 7. Balwara - Birana - Sena window of IRS-IC, LISS III image showing Siwana (S) granites in the NW, Balwara (B) lineament, Sukri river (SR), Jalor (J), Bara (BR), Khari river (K), Bandi river (BN) and Sena (SN). The Luni-Sukri lineament follows Birana (BI) - Mandwala (MA) line.

valley fill regions can be observed in the region between the west of Jalor and to the west of Mera. It can be observed that the rivers coming from both ridge sides get defunct and disorganized in the valley fill (Location D, figure 9). Rectangular and braided pattern as a result of tectonic adjustment is indicated by Sukri river to the NE of Jalor. The Sukri river follows NE-SW trend following dissected pediment-valley fill region. The urbanization and agriculture is mostly in the valley fill- pediment region, where the groundwater is relatively fresh. Such areas are common to the east and southeast of Jalor and to the south of Mera (figure 9).

\subsection{Balwara - Jalor window}

This window encompasses Balwara - Mandawala Jalor region (figure 10). In this window also the drainages incise over the buried pediment area and 


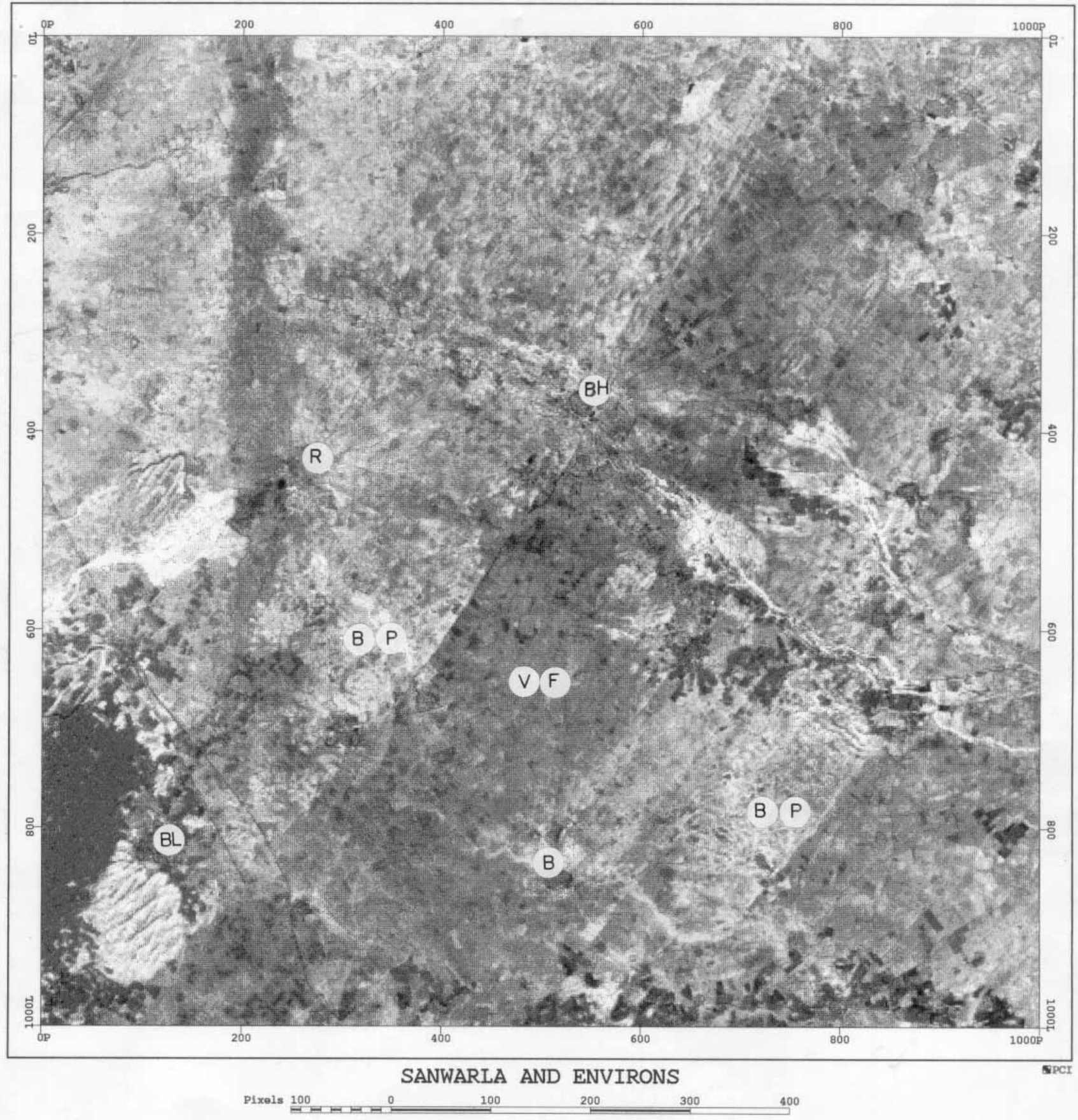

Figure 8. Balwara - Bharwani window of IRS-1C, LISS III image showing Raithal - Sanwarla lineament (north of Raithal). Mithri river from east passes over Buried pediment (BP) and valley fill (VF) to the north of Bhavrani (B), Raithal (R), Balwara (BL) and Bharwani (BH).

get disorganized in the valley fill. The main feature of this window is the course of the Sukri river to the north of Jalor, where the river makes a large loop in the valley fill region and finally adjusts to relatively straight and braided channel. The channel areas provide a good intensity of vegetation and availability of fresh groundwater.

\subsection{Bhadrajan - Sankwali window}

This window is typical of oval ridges surrounded by pediments and valley fill areas. There is a sharp tonal contrast among the ridges, pediment and valley fill. While the ridges appear dark grey, the pediments are yellowish and greenish white, the valley fills appear as dark greenish grey. Quite a 


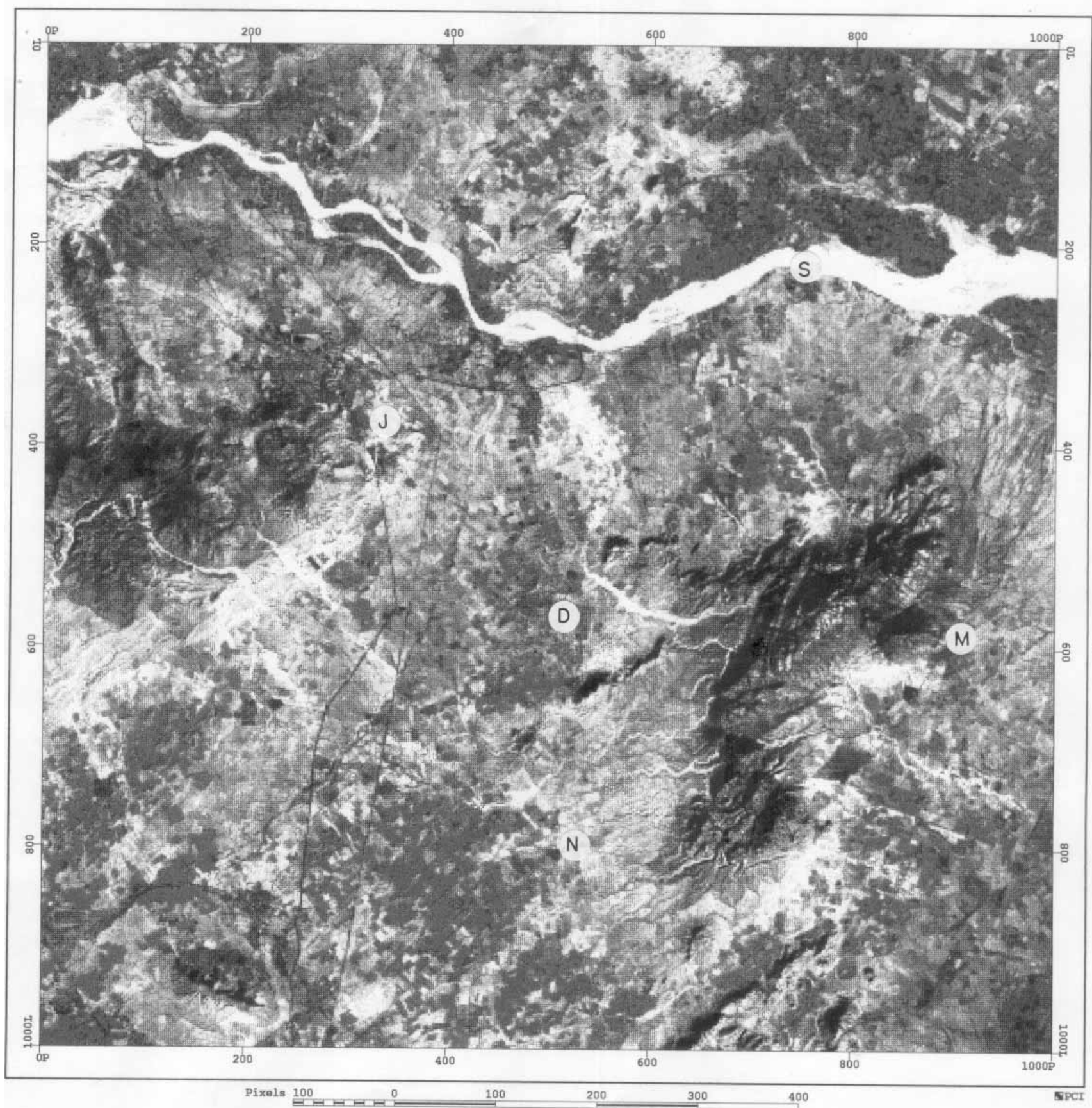

Figure 9. Jalor - Mera window of IRS-1C, LISS III image showing ridges, pediment and valley fill (D) regions. Mera (M), Narnawa (N) and Jalor (J), S - Sukri river.

wide course of the Mithri river passes across these features. The most of the part of Mithri river shows the braided pattern as evident around Sankwali (location S, figure 11). Urbanization is maximum on the buried pediments and a major part of agriculture is on the braided river bed in valley fill area formed by dissected pediments. Four windows, which correspond to active channel lineaments of the Luni river in its N-S section from Tilwara to Gandhav have also been selected for detailed observations. These windows lie between Luni-Sukri lin- eament and the lineament to the east of RabbasarSarli line.

\subsection{Karna - Sindari window}

This window has in its central part the rectangular sector of the Luni river extending from north of Karna to Sindari (figure 12). The rectangular sectors indicate possibly a structural control from basement rocks and are classified as active channel lineaments. Field measurements in the vicinity 


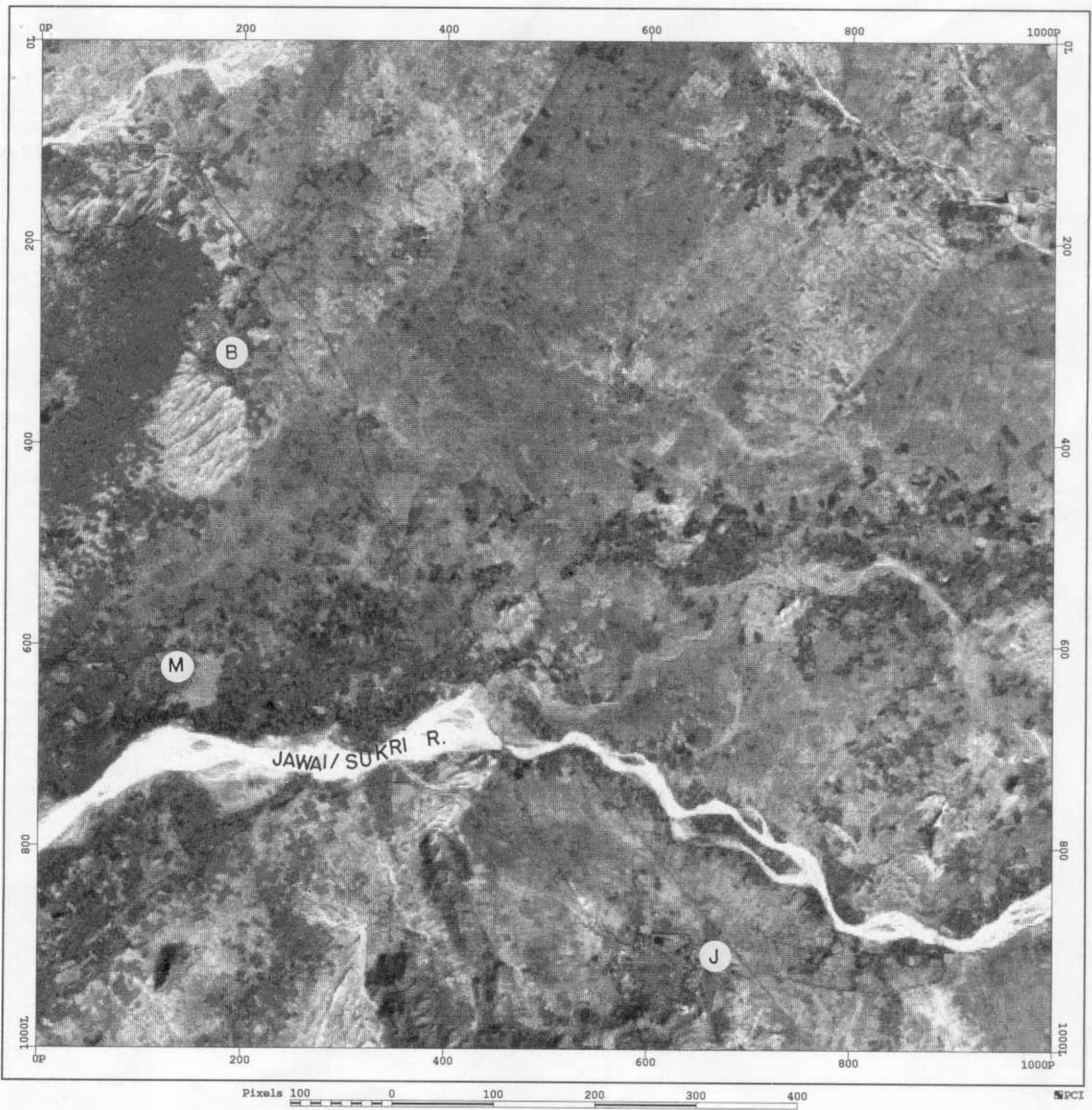

Figure 10. Balwara - Jalor window of IRS-1C, LISS III image showing incision by drainages over buried pediments and disorganization in valley fills. Balwara (B), Mandawala (M) and Jalor (J).

indicate that the major joint patterns in rhyolite trend in NE-SW and NW-SE direction. The joints dip at high angle $\left(75^{\circ}\right.$ to $\left.80^{\circ}\right)$ to vertical. Deepseated conjugate fractures intersecting at Bhukan region have given rise to a rectangular pattern of active channels. However, a similar rectangular pattern is common in the down stream area. Field investigations on Bhukan - Sindari bank of the Luni river, show that fractures with width ranging from $2 \mathrm{~mm}$ to $4 \mathrm{~cm}$ and depth more than $3 \mathrm{~m}$ extend across thick consolidated gravel situ- ated at the bank near Lohira. The trend of the Luni is $220^{\circ} \mathrm{N}$ and fracture trend across the river and riverbank is $140^{\circ} \mathrm{N}$. The Luni river partly follows the fracture trend. The depth to rhyolite at Sindari is about $42 \mathrm{~m}$ and is mostly covered by gritty gravel deposits of typical arid river. The activity along the deep-seated faults thus appears to result into the rectangular pattern. In addition, at Sindari the tonal contrast on IRS FCC images shows an E-W lineament (Bajpai et al 2001b), which may possibly be a fault with its downthrow 


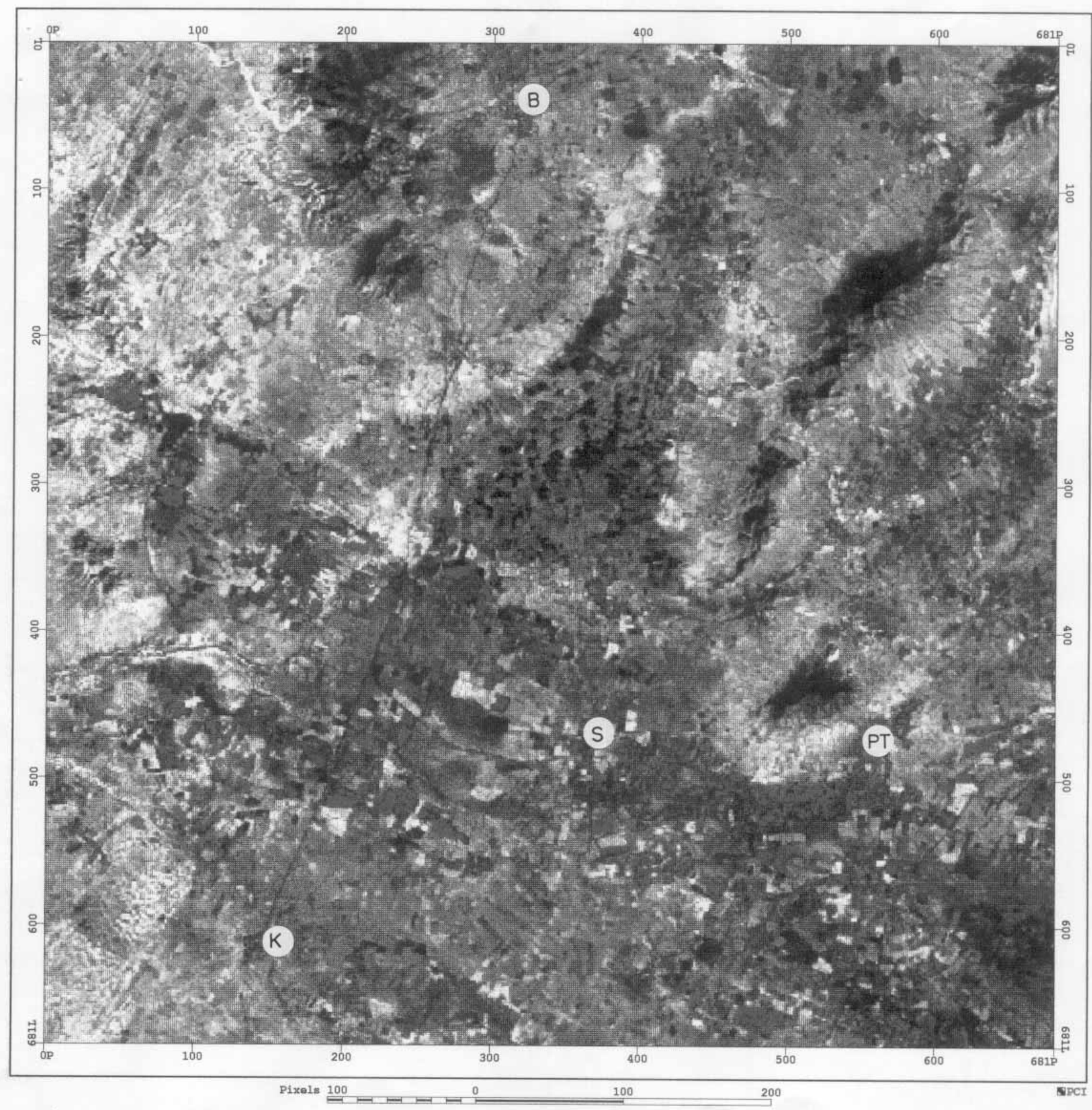

$\uparrow$

Figure 11. Bhadrajan - Sankwali window of IRS-1C, LISS III image showing oval to elongated ridges, pediments and valley fills. A wide course of Mithri river flows from SE to W through valley fills and dissected pediments. Panchhota (PT), Sankwali (S), Bhadrajan (B) and Kamba (K).

towards south. In general the course of the Luni river right from Tilwara (upstream) to Gandhav (downstream) is controlled by a major NNE-SSW trending fault zone as indicated by analysis of Bouguer gravity cross-sections. High gravity gradient on either side of Sindari indicates deep-seated faults, resulting into fault controlled depressions (Bajpai et al 2001a). Also towards downstream of Sindari, a general increase in thickness is expected.
Another outstanding feature of the area is clustering of linear sand dunes which trend NE-SW. At places interdunal areas are sources of groundwater and support agriculture. Such areas are indicated by brownish red.

\subsection{Khudala - Nawanagar - Gura window}

The main feature of this window is straight to meandering and rectangular pattern of the river. A 


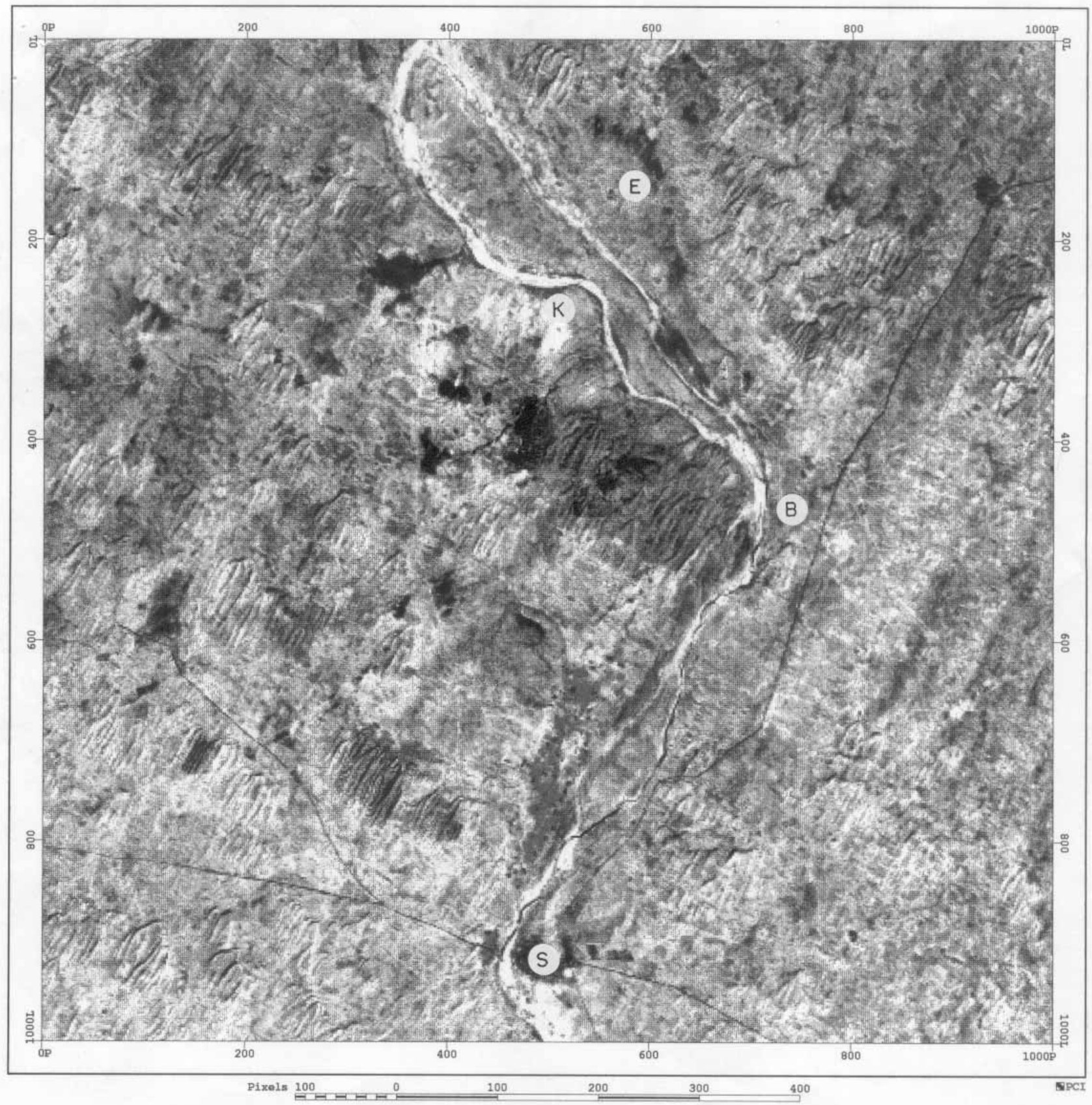

Figure 12. Karna - Sindari window of IRS-1C, LISS III image showing control of Luni river by rectangular joint/fracture pattern. Karna (K), Bhukan (B) and Sindari (S), (E)-excavated sandy pebbly gravel.

relative obliteration of subsurface geological structure at Khudala (figure 13) and to its south is possibly due to a relative deep filling in this area. Gravity analysis also indicates that the center of depression is at Khudala. The presence of a localized laterally pinching coarse sand and gravel body and closed gravity contours $(-30 \mathrm{mgal})$ with sharp gradient from north and west to Khudala also confirms the concentric depression in the basement at Khudala (Bajpai et al 2001a). The Khudala area can be taken as an area of groundwater resource, besides having groundwater in interdunal depressions.

\subsection{Nawanagar - Bateri window}

This window contains the Luni river on its western side and the Sukri on its southeastern side. The main feature besides Khudala (described earlier) is the rectangular pattern of the Sukri river in downstream of Bateri, which appears to be controlled by subsurface geological structures possibly 


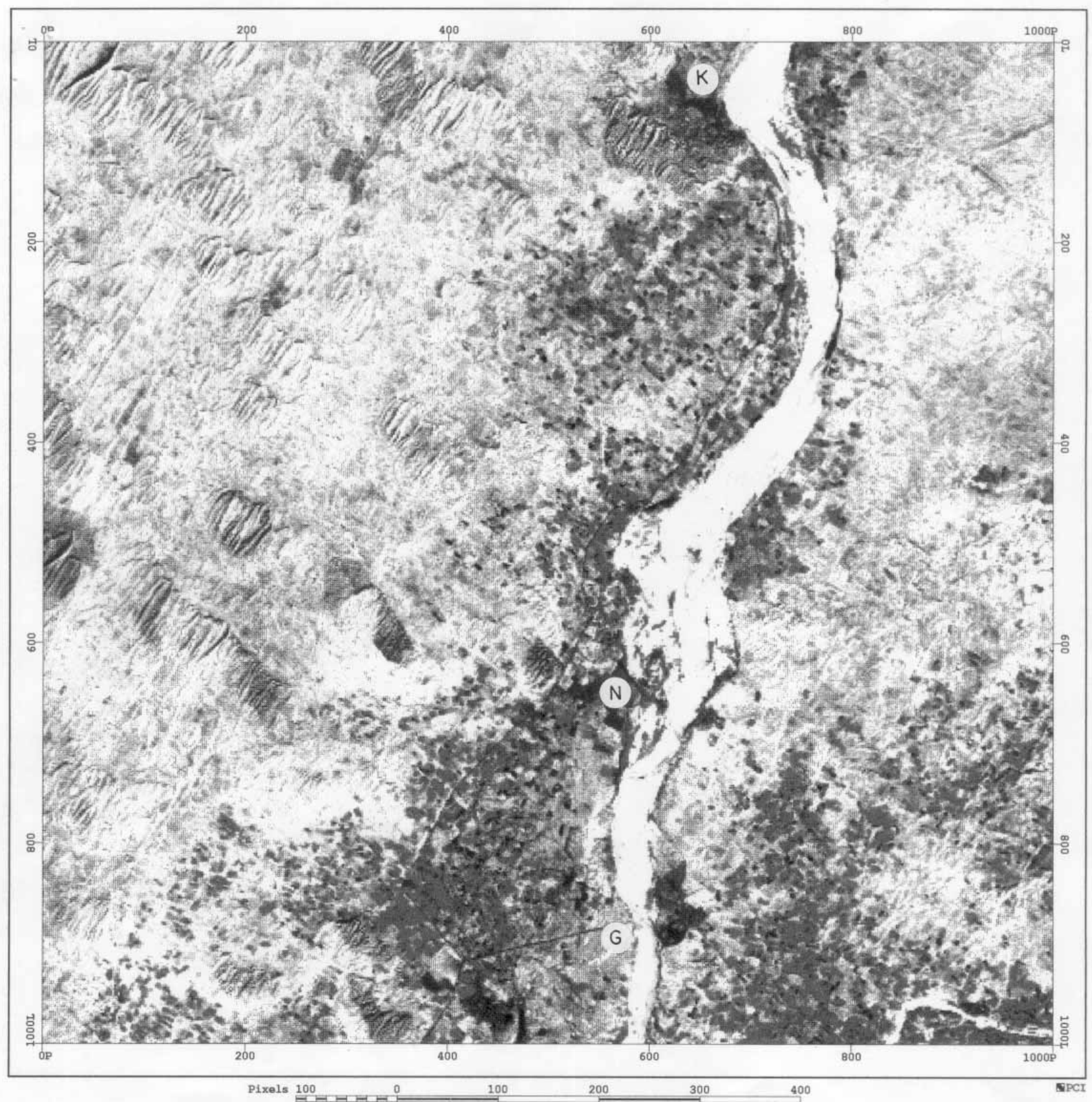

Figure 13. Khudala - Nawanagar - Gura window of IRS-1C, LISS III image showing rectangular drainage at Khudala and a relative straightening towards south. Khudala $(\mathbf{K})$, Nawanagar $(\mathbf{N})$ and Gura $(\mathbf{G})$.

faults (trends approximately E-W and NE-SW, figure 14).

\subsection{Chhotan - Gandhav window}

This scene belongs to IRS-1C LISS III (P91R54) and is a result of Adaptive Equalization Enhancement. This window has in its western part the international boundary and towards east the Luni river and Rann of Kutchch. Part of the terrain towards west is out of the present
Luni basin, however, the infiltrated water joins the main Luni river. The Luni river is marked by part of the active channel Luni-Sukri lineament passing through Gandhav (location G, figure 15). This scene is conspicuous of a NE-SW trending tonal lineament occurring to the west of the Luni-Sukri lineament and parallel to the same. The tone is dark pinkish grey and green to the east and greenish white to the west of this lineament. This lineament is a part of the Rabbasar-Baorli lineament (Bajpai et al 2001a), 


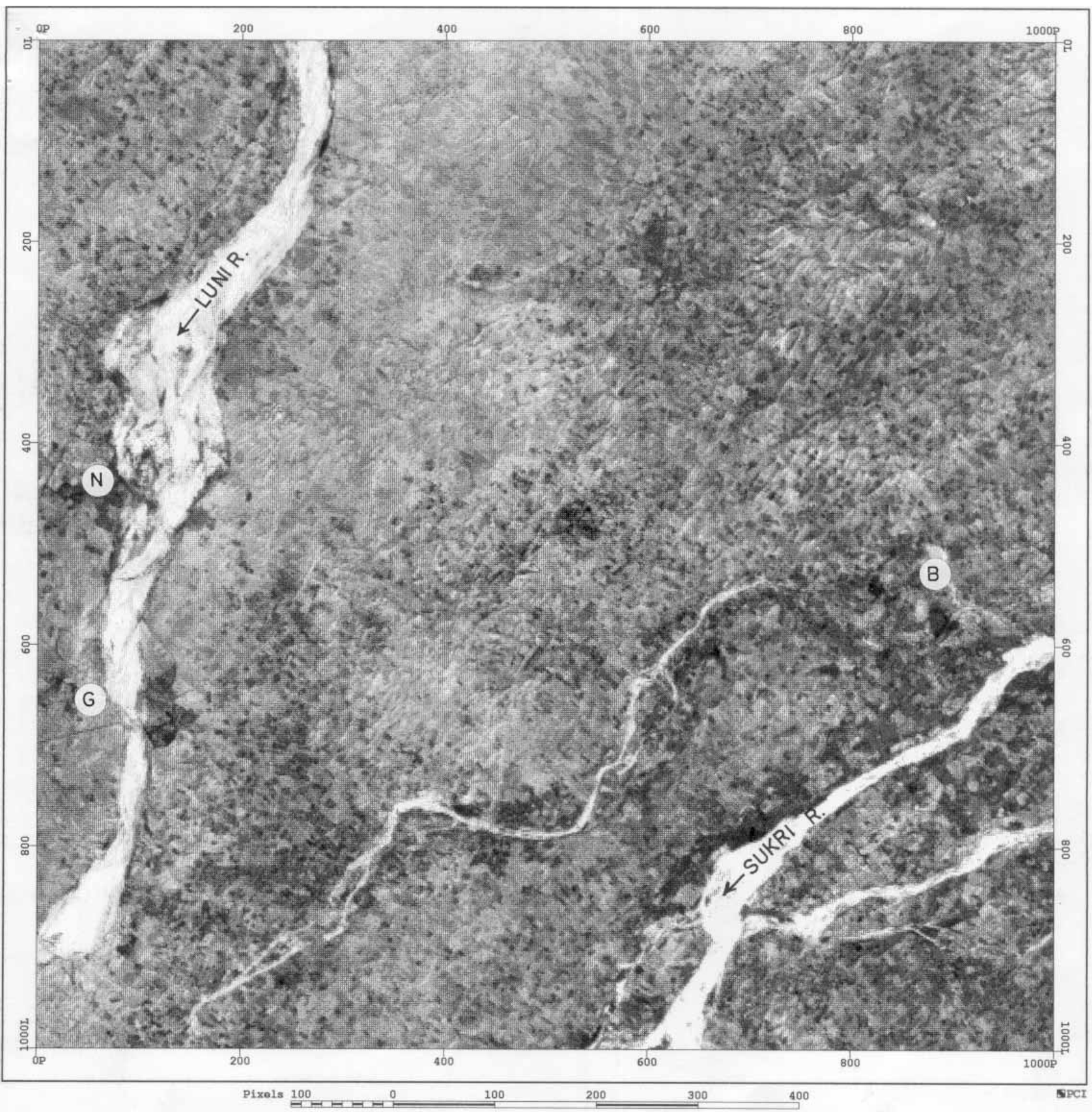

Figure 14. Nawanagar - Bateri window of IRS-1C, LISS III image showing rectangular pattern of Sukri river to the SW of Bateri, possibly controlled by subsurface geological structure. Nawanagar (N), Gura (G) and Bateri (B).

however, analysis of the tonal distribution indicates that the lineament in its southern part is to the east of the Rabbasar-Sarli line and passing somewhere halfway between the Chhotan and Gandhav following NE-SW trend. In the Barmer region, the lineament shows faulted contact of Cretaceous-Carboniferous formations and consolidated sediments/volcanics with Malani rhyolite, and granite (GSI, 1982). The lineament is sensitive to the occurrence of georesources e.g., petroleum and groundwater.

\section{Discussion and conclusions}

The following observations and conclusions are summarised:

- The Luni basin is an active tectonic sedimentary basin where deposition has taken place on an uneven basement in the form of alternating horst and graben structures from east to west. Earlier analysis of Bouguer anomaly profiles (Bajpai et al 2001a) also indicates that the basement has 


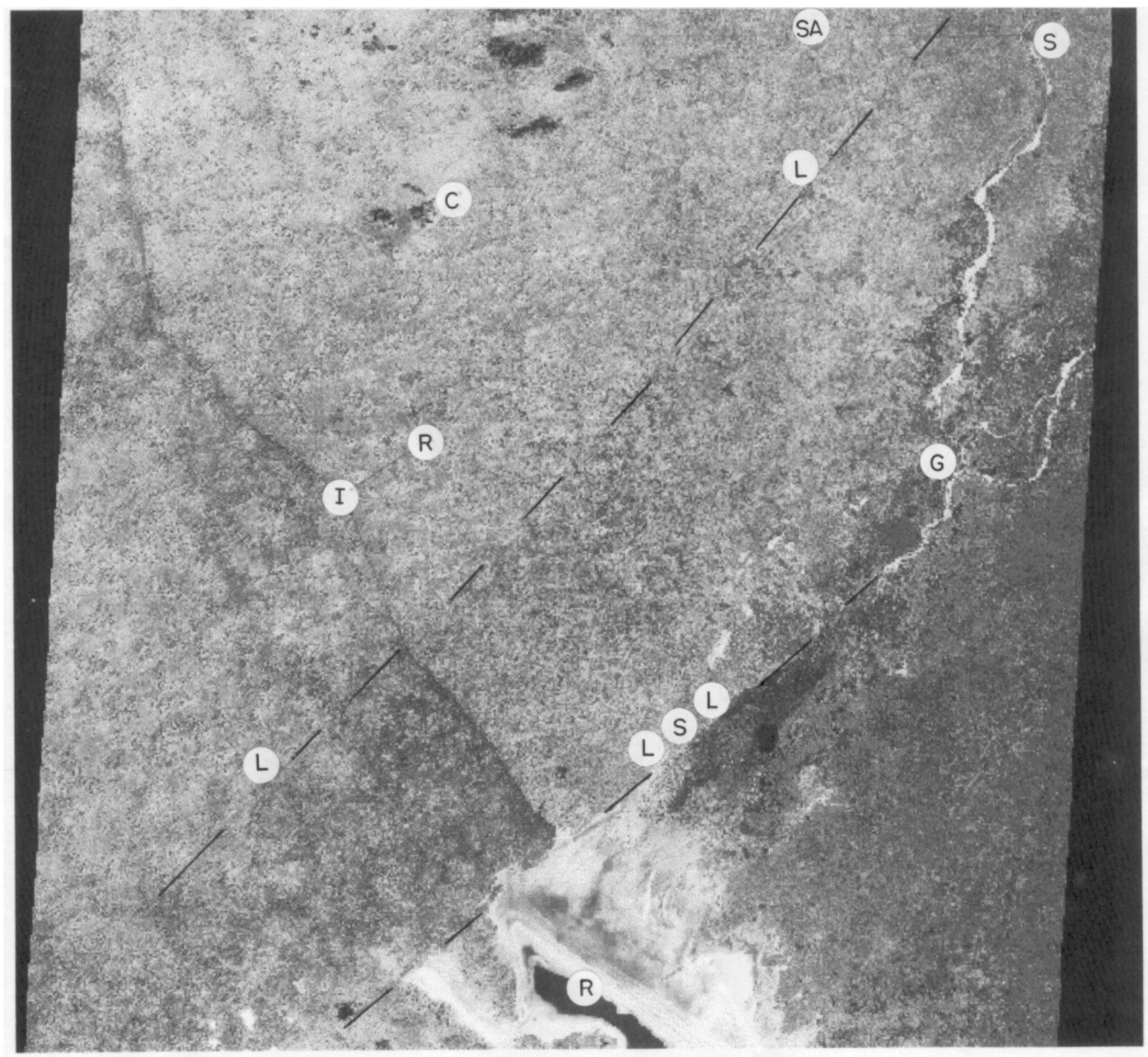

Figure 15. Chhotan - Gandhav window of IRS-1C, LISS III image showing Luni-Sukri lineament (LSL) and part of Rabbasar - Baorli lineament (L-L). Rann of Kutchch (R), Gandhav (G), Sindari (S), Sarli (SA), Rabbasar (R), International border (I) and Chhotan (C).

been activated along horst and graben structures and as a result, most of the present river systems align and lie within the gravity lows (grabens).

- The depth to basement varies from few meters towards western and central parts of the basin and to more than $300 \mathrm{~m}$ to the SW of Jalor in the Sanchor-Haryali region. In the NE near Merta city it is about $45 \mathrm{~m}$, however to the south of Merta thickness increases to about $150 \mathrm{~m}$. In the western part near Sindari this ranges from about $40 \mathrm{~m}$ to $70 \mathrm{~m}$.

- Initially the basin has uneven basement consisting of Erinpura granite and Malani rhyolite with Bilara limestone, Girbhakar and Sonia sandstone (Marwar Supergroup). In the west, out of the basin in Barmer district the rhyolite occurs in faulted contact with Lathi sandstone (Cretaceous-Carboniferous). In such a basin the records of Quaternary deposition showing a sequence of pebbly-cobbly conglomerate, gravel, coarse sand, fine sand, calcrete, clay and fine sand are present.

- In the western part of the basin the optical ages indicate older deposits near Khudala (dated to $>90 \mathrm{ka})$ at the beginning of Late Pleistocene (Jain and Tandon 2003). Around 14 ka there is a resumption of fluvial activity that showed incision and deposition by gravel bedload braided 
streams (OIS 1). OIS 1 between 11 and $14 \mathrm{ka}$ showed a spectrum of gravel sand braided, meandering, sandy ephemeral streams and aeolian. The second phase of incision occurred during the early Holocene followed by sheet flow aggradations between 5 and 9 ka. Finally during the arid phase around $3 \mathrm{ka}$ streams become defunct and only aeolian dunes remain on stratigraphic record. After $3 \mathrm{ka}$ the wet phase gave rise to incision resulting into the present day sandy Luni river channel (Jain and Tandon 2003).

- The processes of incision and braiding are well exhibited by Mithri (Sankwali - Panchhota region) and Sukri (Balwara - Jalor region), which require further study regarding age determination together with climate analysis.

- General observations show that depth to the basement along the Luni-Sukri lineament, increases towards SW and slowly decreases towards NE. On an imagery, this is indicated by pink tone along Sukri river (S of Jalor) and dark greenish tone to the NE of Jalor.

- Geomorphologically, the rocky tract, buried pediments and valley fills are indicated with a sharp contrast on IRS - LISS III images. It is easy to see the dark green areas as valley fills in contrast to greenish-white pediments on digitally processed images.

- Rivers while flowing from east to west have hydrodynamically adjusted to the buried pediment and valley fill structures as these incise the areas of buried pediments and braid, disorganize and defunct in valley fill regions.

- The braiding is typical for a river adjusting on slopes in arid region, due to quick filling, however the same in humid region corresponding to slow uplift gives rise to sinuosity. The changes in depositional material from coarse and mixed of all size grades to fine requires more study on climatic changes in the region.

- Lineaments trending NE-SW, NW-SE and E-W indicate the adjustment of various streams flowing across them. This is conspicuously visible along Sukri and Mithri river systems. The lineaments show tectonic control and depositional behaviour of streams.

- Regarding geological and georesource point of view the Luni-Sukri, Jaisalmer-Barwani, and the lineament to the east of Rabasar-Sarli extending to Baorli are important for groundwater reservoir and petroleum occurrence.

- Thus an overall analysis of lineaments and hydrogeomorphic processes together with gravity profiles indicate a hydrogeological evolution of the Luni basin. Initially it was an uneven basement in the hard rock with several faults trending mostly NE-SW, NW-SE and E-W. Sudden downpouring of sediments in the grabens have filled them maintaining the geomorphic adjustments of the rivers during subsidence. The deposition has started with clay and ended with multistoried sand and gravel sequences fining upwards. The activation along faults is still visible on satellite images (straight drainages) and occurrence of earthquakes in the region.

\section{Acknowledgements}

Liberal funding for carrying out these studies has been provided under the DST project ESS/CA/A3-08/92B to S K Tandon as Principal Investigator. Discussions with Dr. Amal Kar of CAZRI, Jodhpur and joint field work with Dr. R P Dhir, CAZRI, Jodhpur and Prof. S N Rajguru of Deccan College of Postgraduate studies, Pune are gratefully acknowledged. The author deeply acknowledges the help given by A S Rajawat in the preparation of digitally processed images in part of the Luni basin at SAC, Ahmedabad. The author is thankful to Shri. D C Sharma, Chief hydrogeologist, Groundwater department, Jodhpur for library consultation and really appreciates the constant encouragement given by Prof. A K Singhvi and Prof. S K Tandon for writing this paper. Author thanks Nitin Bhardwaj for help in preparation of this manuscript. Reviews by experts helped in improvement of the text.

\section{References}

Abdullatif O M 1989 Channel - fill and sheet - flood facies sequences in the ephemeral terminal River Gash, Kassala, Sudan; Sedimentary Geology 63 171-184

Bajpai V N and Fallah Pour T M 1998 Lineament mapping on satellite images for deciphering hydrogeologic situation in Banas river basin, Rajasthan, India. In: Remote Sensing in Geosciences Tripathi, N K and Bajpai, V $\mathrm{N}$ (eds), pp. 283-300. (New Delhi: Anmol publication) $300 \mathrm{pp}$

Bajpai V N Saha Roy T K and Tandon S K (2001a) Subsurface sediment accumulation patterns and their relationships with tectonic lineaments in the semi-arid Luni river basin, Rajasthan, Western India; Journal of Arid environments 48 603-621

Bajpai V N Saha Roy T K and Tandon S K 2001b. Hydrogeomorphic mapping on satellite images for deciphering regional aquifer distribution: case study from Luni river basin, Thar Desert, Rajasthan, India; Proceedings - International Conference on regional aquifer systems in arid zones - managing non-renewable resources. Tripoli, Libya, 20-24 November 1999, pp. 45-58

Bakliwal P C and Wadhawan S K 2003 Geological evolution of Thar desert in India - Issues and prospects; Proc. Ind. Nat. Sci. Acad. 69A(2) 151-165

Bell F C 1979. Precipitation. In: Goodall D W and Perry R A (eds), vol. 1, pp. 373-392. (London: Arid land ecosystems Cambridge University Press) 881 pp 
Burnett A W and Schumm S A 1983 Alluvial - river response to neotectonic deformation in Louisiana and Mississippi; Science 222 49-50

Das Gupta S K and Chandra M 1978 Tectonic elements of the West Rajasthan Shelf and their stratigraphy; Quarterly Journal of the Geological, Mining and Metallurgical Society of India $\mathbf{5 0} 1-16$

Dhir R P, Kar A, Wadhawan S K, Rajaguru S N, Misra V N, Singhvi A K and Sharma S B 1992. Lineaments, In: Singhvi, Thar Desert in Rajasthan: land, man and environment, A.K. and Kar, A. (eds), pp 29-32. (Bangalore: Geological Society of India.) $191 \mathrm{pp}$

Enzel Y, Ely L, Mishra S, Ramesh R, Amit R, Lazar B, Rajguru S N, Baker V R Sandler A 1999. High - resolution Holocene environmental changes in the Thar desert, northwestern India; Science 284 124-128

Goudie A and Wilkinson J 1977 The warm desert environment. (London: Cambridge University Press) $80 \mathrm{pp}$

GSI (Geological Survey of India) 1976 Atlas of Rajasthan: Geology and Minerals. (Jaipur: Geological survey of India)

GSI (Geological Survey of India) 1982 Tectonic map of South and East Asia, (1 $1^{\text {st }}$ Edn.) (Hyderabad: Geological Survey of India)

Gupta S N, Arora Y K, Mathur R K, Iqbaluddin, Parsad B, Sohai T N and Sharma S B 1980 Lithostratigraphic map of Aravalli region: Southern Rajasthan and Northern Gujrat. (Geological Survey of India)

Henry A, Saktawat U S and Paliwal B L 1983 Groundwater resources of Jalor district, Part 1, Hydrogeology; Groundwater department, Pali: Govt. of Rajasthan

Heron A M 1917 Geology of Northeastern Rajputana and adjacent districts; Mem. Geol. Surv. India, $\mathbf{4 5}$ pt.1, pp. 1128

Jain M; Tandon S K; Bhatt S C Singhvi A K and Mishra S 1999 Alluvial and aeolian sequences along the river Luni, Barmer district; physical stratigraphy and feasibility of luminescence chronology methods, pp. 273-295. In: Vedic Saraswati - Evolutionary history of lost river in northwestern India. Memoir, Radakrishna B P and Merh, S.S (eds) $42329 \mathrm{pp}$

Jain M and Tandon S K 2003 Fluvial response to Late Quaternary climate changes, western India; Quaternary Science Reviews, 22: 2223-2235

Jain M, Tandon S K, Singhvi A K, Mishra S, Bhatt S C, 2003 Quaternary alluvial stratigraphic development in desert river: A case study from the western India; 7th International Conference on Fluvial Sedimentology 2001, Lincoln, Nebraska, Proceeding volume, in press.

Jones K R 1981 Arid Zone Hydrology Rome: Food and Agricultural Organization of the United Nations. 272 pp

Kar A 1992 Geomorphology of the Thar Desert in Rajasthan. In: Sharma H S and Sharma M L (eds), Geographical Facets of Rajasthan, pp. 298-314, Ajmer: Kuldeep Publications.

Kar A 1994 Lineament control on channel behaviour during the 1990 flood in the southeastern Thar Desert; International Journal of Remote Sensing, 15 25212530

Kar A, 1999 A hitherto unknown palaeodrainage system from the radar imagery of southeastern Thar desert and its significance; Memoir Geological Society of India, No. $42229-235 \mathrm{p}$

Laronne J B and Reid I 1993 Very high rates of bedload sediment transport by ephemeral desert rivers; Nature 366 148-150

Mishra S, Jain M, Tandon S K, Singhvi A K, Joglekar P P, Bhatt S C, Kshirsagar A, Naik S and Mukherjee 1999 Prehistoric Cultures and Late Quaternary environments in the Luni basin around Balotra; Man and Environment 24 (1), 38-49

Mishra S and Rajaguru S N 2001 Late Quaternary Palaeoclimates of Western India: A Geoarchaeological Approach; Mausam 52: 285

Ouchi S 1985 Response of alluvial rivers to slow active tectonic movement; Geol. Soc. Am. Bull. 96 504-515

Pareek H S 1981 Basin configuration and sedimentary stratigraphy of Western Rajasthan; J. Geol. Soc. India, 22: $517-527$

Pareek H S 1984 Pre-Quaternary geology and mineral resources of northwestern Rajasthan; Memoir Geological Survey of India 115 1-99

Pal G N 1991 Quaternary landscape and morphostratigraphy in the lower reaches of the Luni basin. In: Proceedings of Quaternary landscape of Indian Subcontinent, Desai N, Ganpathi S and Patel R K (eds), pp 79-90. Vadodra, Geology Department, M.S. University, Baroda.

Pilgrim D H, Chapman T C and Doran D G 1988 Problems of rainfall - runoff modeling in arid and semi-arid regions. Hydrological Sciences Journal, 33 379-400

Ramasamy S M, Bakliwal P C and Verma R P 1991 Remote Sensing and river migration in western India; International Journal of remote Sensing, 12 2597-2609

Reid I and Frostick L E 1987 Flow dynamics and suspended sediment properties in arid zone flash floods; Hydrological Processes, 1: 239-253

Roy A B and Jakhar S R 2001 Late Quaternary drainage disorganisation and migration and extinction of the Vedic Saraswati; Current Science, 81 1188-1195

Roy B C 1959 The economic geology and mineral resources of Rajasthan and Ajmer; Geological Survey of India $\mathbf{8 6}$ $386 \mathrm{pp}$

Sabins F 1987 Remote Sensing: Principles and Interpretations. (San Francisco: W.H. Freeman \& Company.) $426 \mathrm{pp}$

Sareen B K 2003 Quaternary stratigraphy of North Gujarat alluvial plains and interpretation of neotectonic evidences - a review; Proc. IV S. Asia Geol. Cong. (GEOSAS IV) $51-63$

Sharma K D and Chatterji P C 1982 Sedimentation in Nadis in the Indian arid zone; Hydrological Sciences Journal 27 $345-352$

Sharma K D, Vangani N S, Choudhari J S, 1984 Sediment transport characteristics of the desert streams in India; Journal of Hydrology 67 261-272

Wadhawan S K, Sareen B K, Pal N K and Raghav K S 1999 Geological and geoenvironmental evaluation of the Thar desert, Rajasthan and Gujarat; Rec. Geol. Surv. India 129(7) 67-69

Wheater H S 2002 Hydrological processes in arid and semiarid areas. In: Hydrology of Wadi Systems. H S wheater and R A Al-Weshah (eds) UNSCO IHP-V Technical Documents in Hydrology $\mathbf{5 5}$ pp. 5-22 